Altai State University

Rcta 3iwlogica Sibirica

Journal of Biology

Founded in 2015

\title{
New materials for flora of vascular plants of the middle stream of Kara river (north-east of the Bolshezemelskaya tundra)
}

\author{
I. A. Savinov \\ Moscow State University of Food Production, Volokolamskoye shosse, 11, Moscow, 125080, Russia
}

\begin{abstract}
A new actual material (for the last 10 years) on the flora of vascular plants, received in the time of summer 2017 year expedition to North-East of Bolshezemelskaya tundra is presented. Total number of the species registrated is 97; the genera - 74, the families - 34. New localities for a number of species were identified (Caltha arctica R.Br., Ranunculus pedatifidus var. affinis (R. Br.) L.D. Benson, R. reptans L.), including those included in regional red books (16 species). Three new species are presented for the region (Viola epipsiloides Löve et D. Löve, Galium densiflorum Ledeb., Artemisia norvegica Fries). In the regional lists of protected plants, it is proposed to include two more species, Ranunculus pedatifidus var. affinis (R. Br.) L.D. Benson and Caltha arctica R.Br.

Key words: flora, vascular plants, Bolshezemelskaya tundra, Kara river, Polar Ural
\end{abstract}

\section{Новые материалы к флоре сосудистых растений среднего течения реки Кары (северо-восток Большеземельской тундры)}

\begin{abstract}
И. А. Савинов
ФГБОУ ВО «Московский государственный университет пищевых производств», Волоколамское шоссе, д. 11, Москва, 125080, Россия. E-mail: savinovia@mail.ru
\end{abstract}

Представлены новые (за последние 10 лет) материалы по флоре сосудистых растений, полученные во время экспедиции на северо-восток Большеземельской тундры в июле 2017 г. Общее число зарегистрированных видов 97, родов - 74, семейств - 34. Выявлены новые местонахождения для ряда видов (Caltha arctica R.Br., Ranunculus pedatifidus var. affinis (R. Br.) L.D. Benson, R. reptans L.), в том числе включенных в региональные Красные книги (16 видов). Приводятся три новых для региона вида (Viola epipsiloides Löve et D. Löve, Galium densiflorum Ledeb., Artemisia norvegica Fries). В региональные списки охраняемых растений предложено включить еще два вида, - Ranunculus pedatifidus var. affinis (R. Br.) L.D. Benson и Caltha arctica R.Br.

Ключевые слова: флора, сосудистые растения, Большеземельская тундра, река Кара, Полярный Урал. 


\section{Введение}

Несмотря на большое количество работ, изучение растительного покрова арктических регионов России сохраняет свою актуальность. Традиции изучения северных регионов страны были заложены выдающимися отечественными ботаниками, профессорами А.И. Толмачевым (1903-1979), Б.А. Тихомировым (1909-1976), Б.А. Юрцевым (1932-2004), А.П. Хохряковым (1933-1998), В.Б. Куваевым (1918-2009) и некоторыми другими. Флора и отчасти растительность востока Большеземельской тундры, находящейся на стыке Полярного Урала и хребта Пай-Хой (геологически являющегося продолжением первого), были детально изучены в конце 50-х и в течение 60-х гг. XX века О.В. Ребристой (1977). Из первых исследований важно упомянуть интересные наблюдения и данные А.И. Шренка (цит. по изданию: Шренк, 2009), совершившего большую экспедицию на северо-восток Европейской России в 1837 году и собравший обширный ботанический материал. Флористические связи Приуралья с Сибирью подчеркнул в своей работе Ф.И. Рупрехт (1856), написанной на основании сборов и наблюдений ботаника Т. Бранта, путешествовавшего под руководством Э.К. Гофмана в 1847 и 1848 гг. Брант посетил, в частности, долинный участок реки Кары. Большие гербарные материалы были получены Карской экспедицией лета и осени 1936 года, хранящиеся в гербарии МГУ (MW, сборы Ф.С. Леонтьева, этикетки рукописные и часто неразборчивы). Следует сказать, что эти сборы не были упомянуты и учтены в сводке О.В. Ребристой (1977). В работе О.В. Ребристой (1977) дан обзор истории ботанического изучения региона.

Итак, последние детальные исследования флоры и растительности Большеземельской тундры были выполнены более 40 лет назад (Ребристая, 1977). Кроме того, они слабо затронули большую часть среднего течения р. Кары. Новые данные, полученные преимущественно в 80-90-х гг. прошлого века, были приведены в ряде публикаций уральских и московских ботаников (Кулиев, Морозов, 1988, 1991; Растительный покров..., 2006). Краткий конспект флоры сосудистые растений республики Коми был опубликован сравнительно недавно (Мартыненко, Груздев, 2008). Следует добавить, что крайний северо-восток Большеземельской тундры - это Европейский сектор Арктики, интересный в ботаническом отношении регион, где встречаются флоры Европейского и Западносибирского севера, и проходят восточные или западные границы ареалов целого ряда видов сосудистых растений. Для некоторых видов мы встречаем здесь переходную зону с возможностью гибридизации близких таксонов (как, например, у Trollius, Galium). Существует также проблема внутривидового многообразия и внутривидовой изменчивости (выделяемые разными авторами формы, разновидности, подвиды в пределах широко распространенных видов; представления о «географических расах» в рамках политипической концепции вида) в крайних северных условиях существования (например, Parnassia palustris L. subsp. neogaea (Fern.) Hult., многочисленные расы Thymus). Она нуждается в дальнейшей разработке.

Долина среднего и нижнего течения р. Кары - район традиционного природопользования кочевых народов - оленеводов Севера (ненцев, коми), что ставит вопрос о необходимости постоянного мониторинга состояния всего природного комплекса (здесь, например, много интересных геологических обнажений мраморных и доломитовых каньонов, отмечены редкие виды птиц и бабочек, совместно обитают европейский и сибирский хариус и др.). В связи с промышленным освоением российской Арктики, реализацией мегапроекта «ямал», затрагивающего большие территории на Ямале и Полярном Урале, представляется важной и своевременной современная оценка состояния растительного покрова тундровых сообществ.

\section{Материал и методы исследований}

Летом 2013 года автор имел возможность познакомиться с флорой переходной зоны от южных тундр к лесотундре на крайнем юге полуострова Ямал (Сибирский сектор Арктики), в долине реки Щучья (Савинов, 2014, 2016). Летом 2017 года, в июле, автор экскурсировал в среднем течении реки Кары, стекающей с западных склонов Полярного Урала и текущей через хребет Пай-Хой в Карское море. Был осуществлен водный маршрут (сплав) по р. Каре протяженностью около 150 км, от автомобильного моста через р. Кару (примерно 25 км северо-восточнее заброшенного поселка Хальмер-Ю, напротив хребта Оченырд) до устья крупного левого притока р. Кары - р. Силовояхи. В ходе собственных исследований автором был собран гербарий (30 листов), переданный в МНА. Были учтены сборы Карской экспедиции 1936 года, хранящиеся в МГУ (MW, https://plant.depo.msu.ru/).

В регионе преобладают следующие типы растительности: кустарниковые (ерниковые, ивняковые), дриадовые и осоково-мохово-лишайниковые тундры, ивняки, осоково-пушицевые болота, луга (особенно приснежные, пойменные речные и склоновые речные, озерные), растительность каменистых склонов и скалистых обнажений.

В ходе проведения экспедиционных исследований (16.07-01.08.2017 г.) детально были изучены 12 основных биотопов, расположенных в разных участках среднего течения реки Кары и ее притоков (табл. 1, рис. 1-3). Следует отметить, что пространственное распределение изученных биотопов отличается известной степенью мозаичности, и те или иные растительные группировки встречались в течение всего маршрута, что, в целом, очень характерно для тундровых сообществ.

При определении видов автор следовал основным региональным сводкам: «Арктической флоре СССР», «Флоре Северо-Востока европейской части СССР», «Определителю высших растений Коми АССР». Латинские названия растений даны по сводке С.К. Черепанова (1995), а также электронной ботанической базе данных Тropicos (http://tropicos.org/). Новинки для флоры региона в приводимом ниже конспекте подчеркнуты. 
Таблица 1. Места сбора материала и маршруты

Список опорных точек (места расположения полевых базовых лагерей)

1. Начало сплава, левый берег, GPS-координаты: 6807'06.9"N, 065¹9'28.1"Е, высота 91 м, республика Коми (16.07.2017);

2. Склон левого берега р. Кара около 15 км ниже автомобильного моста, GPS-координаты: 68²'62.8"N, 06517'32.6"Е, высота 102 м, республика Коми (17.07.2017);

3. Устье р. Ладхэйяха, GPS-координаты: $68^{\circ} 21^{\prime} 77.3^{\prime \prime} \mathrm{N}$, 065²5'65.4"Е, высота 72 м, Ямало-Ненецкий АО, Тюменская обл. (18.07.2017);

4. Устье р. Нярмаяха, GPS-координаты: 68³3'40.7"N, 06540'11.3"Е, высота 6 м Ямало-Ненецкий $\mathrm{AO}$, Тюменская обл. (21.07.2017);

5. Устье р. Нерусавэйяха, небольшой каньон, GPSкоординаты: 6841'49.9"N, 065²5'31.7"Е, высота 45 м, Ямало-Ненецкий АО, Тюменская обл. (24.07.2017);

6. Низкий левый берег р. Кара, около 7 км ниже водопада Буредан, GPS-координаты: 6846'81.8"N, 065²3'81.2"E, высота 34 м, Ненецкий АО, Архангельская обл. (25.07.2017);

7. Устье р. Брусьяха, GPS-координаты: 6848'81.2"N, 065²0'06.4"E, высота 41 м Ямало-Ненецкий АО, Тюменская обл. (26.07.2017);

8. Устье р. Силоваяха, GPS-координаты: 6850'42.5"N, 06459'52.9"Е, высота 14 м, Ненецкий АО, Архангельская обл. (29.07.2017);

9. Левый берег р. Хальмерью у водопада (памятник природы «Водопад на р. Хальмеръю»), GPS-координаты: 6807'58.6"N, 064²'40.0"Е, высота 186 м республика Коми (31.07.2017)
Места наблюдений и сбора материала, перечень биотопов

1. Разнотравный западный луговой склон у ручья, подножье хребта Оченырд. GPS-координаты: 6804'35.5"N, 065³0'45.2"Е, высота 367 м;

2. Ивово-ерниковый склон на левом берегу $\mathrm{p}$. Лядхэйяха;

3. Скальник (скальная стенка) на левом берегу р. Лядхэйяха, около 2 км выше устья;

4. Ерниково-осоковая низкокустарниковая тундра в междуречье рр. Кара и Лядхэйяха;

5. Берег озера с широкой полосой травяного болота с ивняками по краям, в междуречье рр. Кара и Лядхэйяха, близ устья последней;

6. Осоково-сфагновая заболоченная тундра с участками ивняков;

7. Разнотравный долинный луг на склоне р. Кары с участками ивняков и низкокустарниковой ерниковой тундры;

8. Осоково-зеленомошная тундра;

9. Склон долины реки со скалистыми берегами (Беломраморный каньон, гряда «Роща Мусюр»), GPS-координаты: 68³0'32.8"N, 065³5'89.3"E, высота 55 м;

10. Мозаика низкокустарниковой мохово-осоковой тундры с пойменными ивняками, GPS-координаты: 6846'81.8"N, 065²3'81.2"Е, высота 34 м;

11. Разнотравно-дриадовая тундра (водопад Буредан), GPS-координаты: 6843'51.9"N, 065²1'80.7"Е, высота 72 м;

12. Заболоченный берег р. Хальмерью

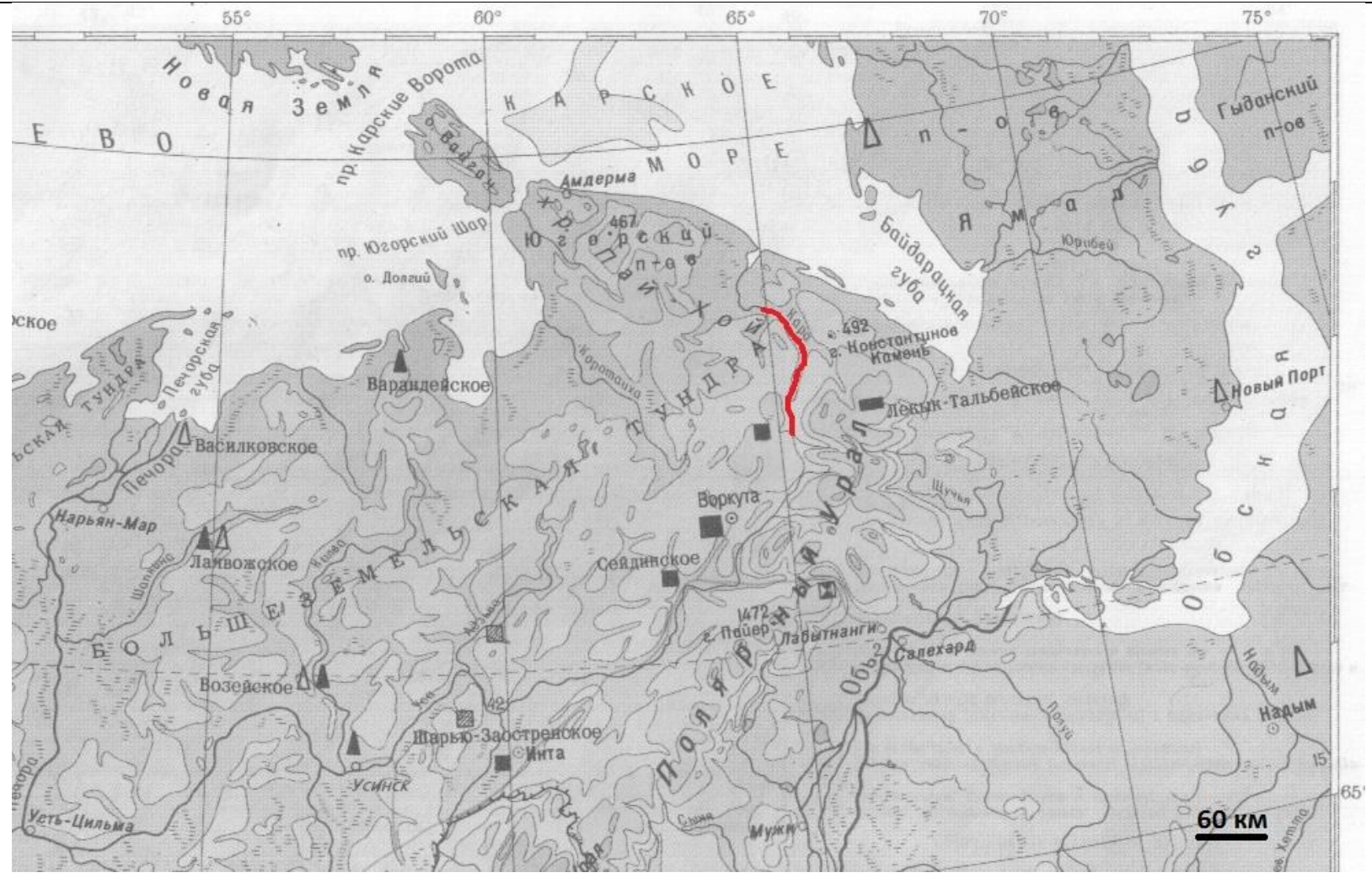

Рис. 1. Маршрут экспедиции (показан красным цветом). 


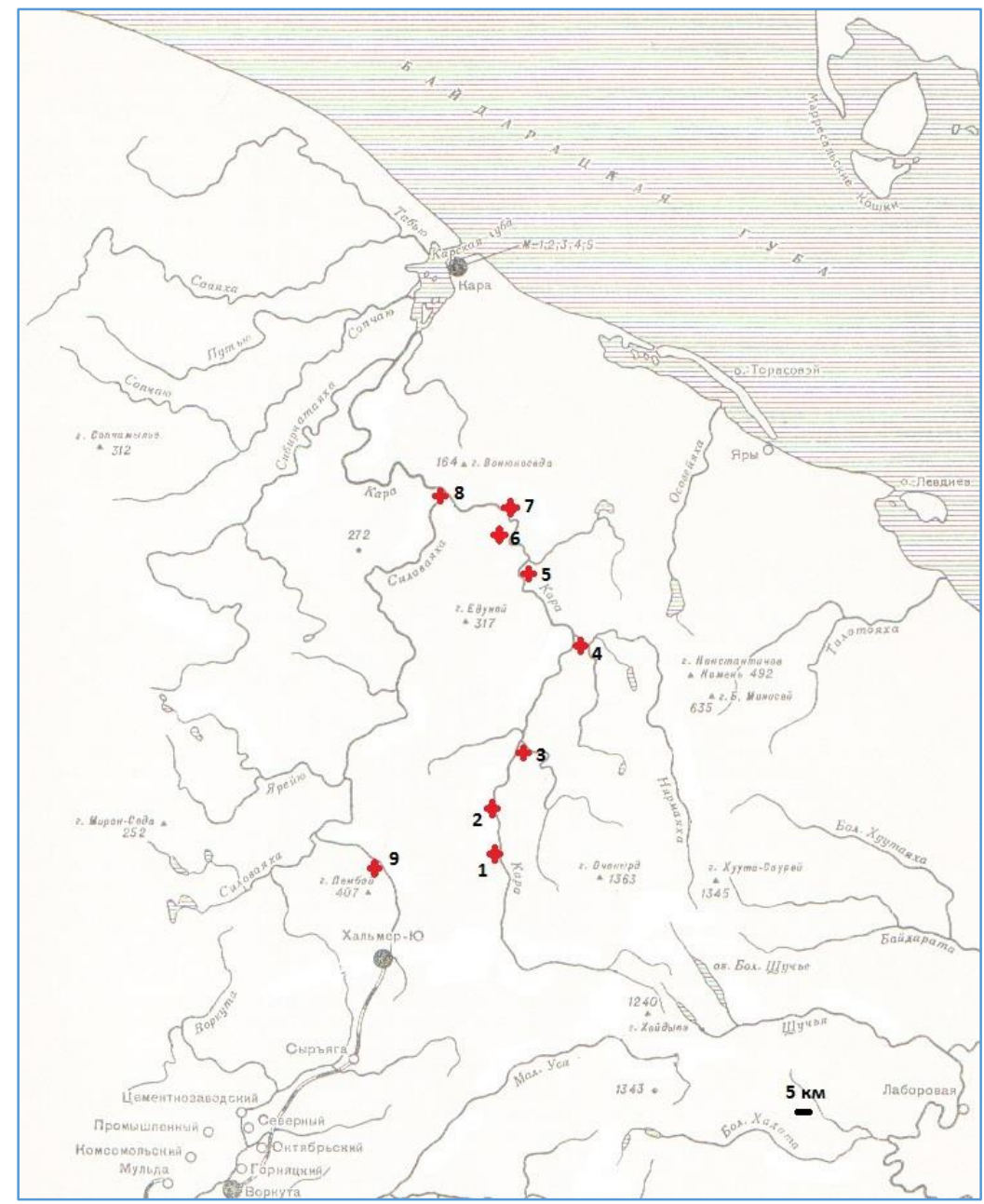

Рис. 2. Места расположения полевых базовых лагерей.

\section{Результаты и обсуждение}

\section{Equisetaceae Rich. ex DC}

1. Equisetum variegatum Schleich. ex Web. et Mohr., 1807, Bot. Taschenb. (Weber) 60: 447; Опред. высш. раст. Коми АССР, 1962: 41; Толмачев, 1960, в Арктич. фл. СССР, 1: 39; Кобелева, 1974, во Фл. северо-вост. Европ. ч. СССР, 1: 56; Ребристая, 1977, Фл. востока Большезем. тундры: 54; Раст. покр. и раст. ресурсы Пол. Урала, 2006: 48; Мартыненко, Груздев, 2008, Сосуд. раст. респ. Коми: 14.

По береговым откосам, заиленным отмелям, берегам ручьев, по незадернованным местам. Сильно увлажненная лужайка на правом берегу р. Кары ниже водопада Буредан, в массе. Изредка в мшистых частях тундры на склонах Беломраморного каньона. (И.А. Савинов, 25.07.2017, МНА).

2. E. arvense L., 1753, Sp. PI. 2: 1061; Опред. высш. раст. Коми АССР, 1962: 39, 40; Толмачев, 1960, в Арктич. фл. СССР, 1: 45; Кобелева, 1974, во Фл. северо-вост. Европ. 4. СССР, 1: 52; Ребристая, 1977, Фл. востока Большезем. тундры: 53; Раст. покр. и раст. ресурсы Пол. Урала, 2006: 48; Мартыненко, Груздев, 2008, Сосуд. раст. респ. Коми: 13. - E. arvense subsp. boreale (Bong.) Tolm., Толмачев, 1960, в Арктич. фл. СССР, 1: 46; Кобелева, 1974, во Фл. северовост. Европ. ч. СССР, 1: 53; Ребристая, 1977, Фл. востока Большезем. тундры: 53. - E. boreale Bong., 1832, Mém. Acad. Imp. Sci. St.-Pétersbourg, Sér. 6, Sci. Math. 2(2): 174)

В регионе представлен северной расой, принимаемой иногда в качестве особого вида. Береговые наносы, склоны, в ивняках по долинам рек, особенно обильно у устья р. Силовояха, иногда в тундре, предпочитает слабо задернованные участки. Рис. 4, С.

\section{Poaceae Barnhart. (Gramineae Juss.)}

3. Arctophila fulva (Trin.) Anderss., 1852, PI. Scand. Cyper., 494; Опред. высш. раст. Коми АССР, 1962: 78; Цвелев, 1964, в Арктич. фл. СССР, 2: 168; Цвелев, 1974, во Фл. северо-вост. Европ. ч. СССР, 1: 200; Ребристая, 1977, Фл. востока Большезем. тундры: 61; Раст. покр. и раст. ресурсы Пол. Урала, 2006: 53; Мартыненко, Груздев, 2008, Сосуд. раст. респ. Коми: 24.

По увлажненным участкам. Обширные заросли на мелководьях тундровых озер и рек, в старицах. 

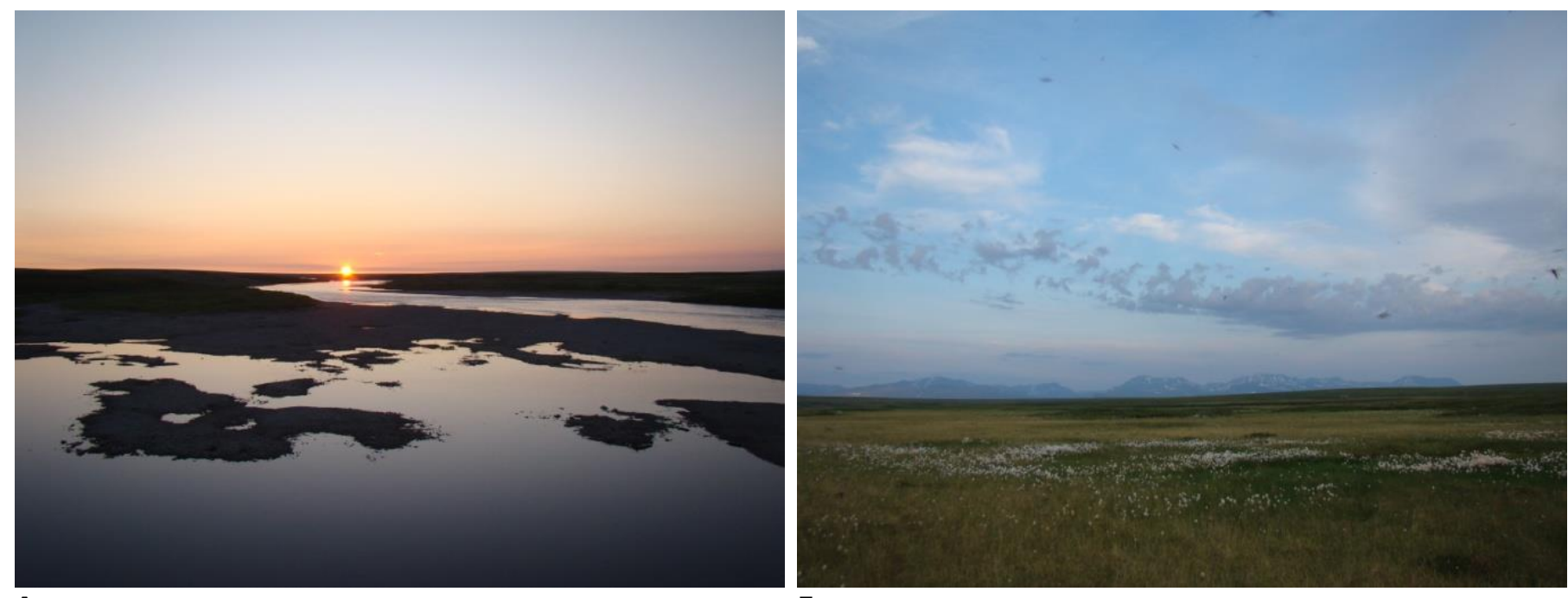

A

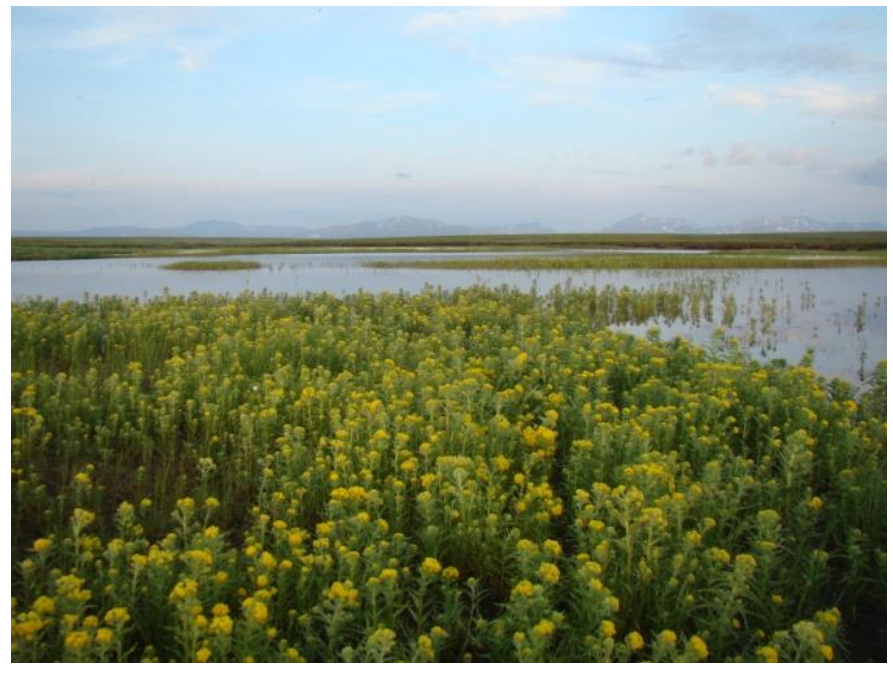

B

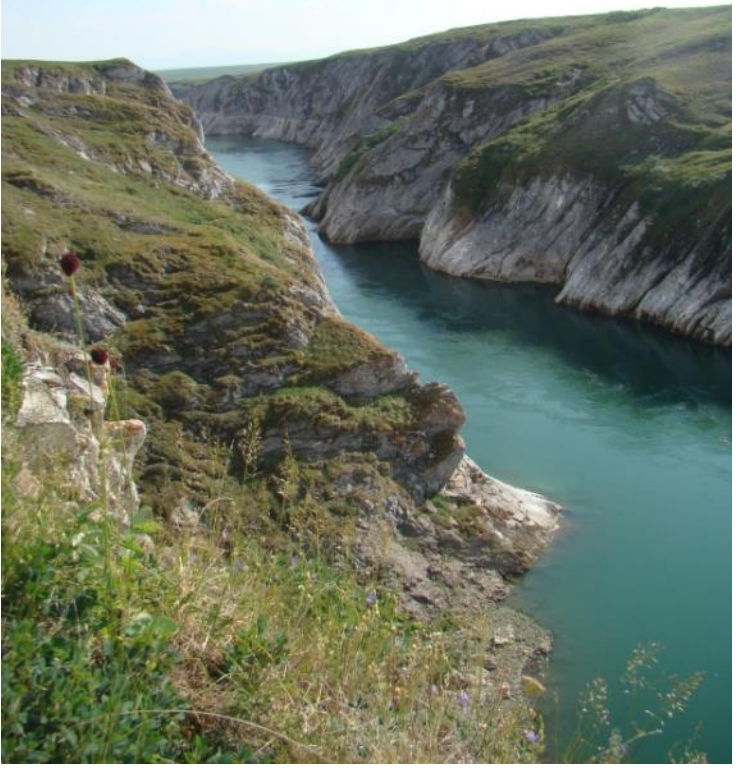

Д

Рис. 3. Разнообразие ландшафтов и растительных сообществ в среднем течении реки Кары: А - общий вид долины реки Кары, Б - Карская тундра, на заднем плане Полярный Урал, В - небольшое озеро в тундре, аспектирует Tephroseris palustris, Г - разнотравно-дриадовая тундра в среднем течении реки Кары у Беломраморного каньона, Д - Беломраморный каньон, Е - Доломитовый каньон в долине р. Нерусавэйяхи. 
4. Poa arctica R.Br., 1823, Chlor. Melvill. 30; Опред. высш. раст. Коми АССР, 1962: 77; Цвелев, 1964, в Арктич. фл. СССР, 2: 127; Цвелев, 1974, во Фл. северо-вост. Европ. ч. СССР, 1: 190; Ребристая, 1977, Фл. востока Большезем. тундры: 60; Раст. покр. и раст. ресурсы Пол. Урала, 2006: 59; Мартыненко, Груздев, 2008, Сосуд. раст. респ. Коми: 31.

Обычное растение разных типов тундр, по увлажненным местообитаниям. Дренированные склоны, низинные осоковые болота. (Ф.С. Леонтьев, 03.08.1936, 24.08.1936, 02.09.1936, 20.09.1936, МW).

5. Dupontia fisheri R.Br., 1823, Chlor. Melvill. 33; Юрцев, 1964, в Арктич. фл. СССР, 2: 166; Цвелев, 1974, во Фл. северо-вост. Европ. Ч. СССР, 1: 201; Ребристая, 1977, Фл. востока Большезем. тундры: 61; Раст. покр. и раст. ресурсы Пол. Урала, 2006: 56.

Заболоченные участки, близ водоемов, старицы рек. Обычный вид. (Ф.С. Леонтьев, 03.08.1936, 15.08.1936, 16.08.1936, 25.08.1936, MW).

\section{Cyperaceae Juss.}

6. Eriophorum scheuchzeri Hoppe, 1800, Bot. Taschenb.: 104, pl. 7; Опред. высш. раст. Коми АССР, 1962: 91; Толмачев, 1966, Арктич. фл. СССР, 3: 20; Егорова, 1976, во Фл. северо-вост. Европ. ч. СССР, 2: 11; Ребристая, 1977, Фл. востока Большезем. тундры: 63; Раст. покр. и раст. ресурсы Пол. Урала, 2006: 69; Мартыненко, Груздев, 2008, Сосуд. раст. респ. Коми: 42.

Хорошо увлажненные минеральные грунты, около снежников. Обычный вид заболоченных тундр и берегов водоемов, в массе. (Ф.С. Леонтьев, 24.08.1936, МW).

7. Eriophorum medium Anderss., 1857, Bot. Not.: 62; Опред. высш. раст. Коми ACCP, 1962: 91 (as syn. E. chamissonis С.А.М.); Толмачев, 1966, в Арктич. фл. СССР, 3: 18; Егорова, 1976, во Фл. северо-вост. Европ. ч. СССР, 2: 11; Ребристая, 1977, Фл. востока Большезем. тундры: 63; Раст. покр. и раст. ресурсы Пол. Урала, 2006: 69; Мартыненко, Груздев, 2008, Сосуд. раст. респ. Коми: 42.

Сырые участки в моховых тундрах, мочажины болот, берега озерков, часто. (Ф.С. Леонтьев, 24.08.1936, МW).

\section{Juncaceae Juss.}

8. Juncus arcticus Willd., 1799, Sp. PI. Ed. quarta 2(1): 206; Опред. высш. раст. Коми ACCP, 1962: 121; Толмачев, 1963, в Арктич. фл. СССР, 4: 25; Лащенкова, 1976, во Фл. северо-вост. Европ. ч. СССР, 2: 97; Ребристая, 1977, Фл. востока Большезем. тундры: 68; Раст. покр. и раст. ресурсы Пол. Урала, 2006: 70; Мартыненко, Груздев, 2008, Сосуд. раст. респ. Коми: 45.

По берегам рек на песчаных, глинистых, реже галечниковых наносах. Разнотравный луг в пойме р. Кары, ниже водопада Буредан. (Ф.С. Леонтьев, 03.08.1936, 12.08.1936, МW).

\section{Liliaceae Juss.}

9. Allium schoenoprasum L., 1753, Sp. PI. 1: 301; Опред. высш. раст. Коми АCCP, 1962: 129; Толмачев, 1963, Арктич. фл. СССР, 4: 64; Кобелева, 1976, во Фл. северо-вост. Европ. ч. СССР, 2: 113; Ребристая, 1977, Фл. востока Большезем. тундры: 70; Раст. покр. и раст. ресурсы Пол. Урала, 2006: 73; Мартыненко, Груздев, 2008, Сосуд. раст. респ. Коми: 47.

Каменистые и песчаные берега рек, отмели, на склонах, в массе. (Ф.С. Леонтьев, 03.08.1936 г., МW).

10. Veratrum lobelianum Bernh., 1807, Neues J. Bot. 2: 356; Опред. высш. раст. Коми АССР, 1962: 127; Толмачев, 1963, в Арктич. фл. СССР, 4: 60; Кобелева, 1976, во Фл. северо-вост. Европ. ч. СССР, 2: 109; Ребристая, 1977, Фл. востока Большезем. тундры: 70; Раст. покр. и раст. ресурсы Пол. Урала, 2006: 74; Мартыненко, Груздев, 2008, Сосуд. раст. респ. Коми: 46.

Обычно на разнотравных береговых склонах, луговинах у снежников, зарослях ивняков.

11. Tofieldia coccinea Rich., 1823, Narr. Journey Polar Sea 736; Толмачев, 1963, в Арктич. фл. СССР, 4: 53; Кобелева, 1976, во Фл. северо-вост. Европ. 4. СССР, 2: 108; Ребристая, 1977, Фл. востока Большезем. тундры: 70; Раст. покр. и раст. ресурсы Пол. Урала, 2006: 73; Мартыненко, Груздев, 2008, Сосуд. раст. респ. Коми: 46.

Изредка в приуральской части территории. Увлажненные склоны Беломраморного каньона, пятна открытого грунта в пятнистых дриадовых и кустарничковых тундрах. (И.А. Савинов, 21.07.2017, МНА). (Ф.С. Леонтьев, 20.08.1936, 01.09.1936, МW). Красная книга НАО, статус 3 (2006), Красная книга Республики Коми, статус 3 (2009)!

12. T. pusilla (Michx.) Pers., 1805, Syn. PI. 1: 399; Опред. высш. раст. Коми АССР, 1962: 127; Толмачев, 1963, в Арктич. фл. СССР, 4: 52; Кобелева, 1976, во Фл. северо-вост. Европ. ч. СССР, 2: 108; Ребристая, 1977, Фл. востока Большезем. тундры: 70; Раст. покр. и раст. ресурсы Пол. Урала, 2006: 73; Мартыненко, Груздев, 2008, Сосуд. раст. респ. Коми: 46. 
Изредка в приуральской части территории. Сыроватые кустарничково-моховые тундры. Увлажненные склоны Беломраморного каньона, на моховинах. Устье р. Нерусавэйяха, небольшой каньон. (И.А. Савинов, 21.07.2017, МНА; И.А. Савинов, 24.07.2017, МНА).

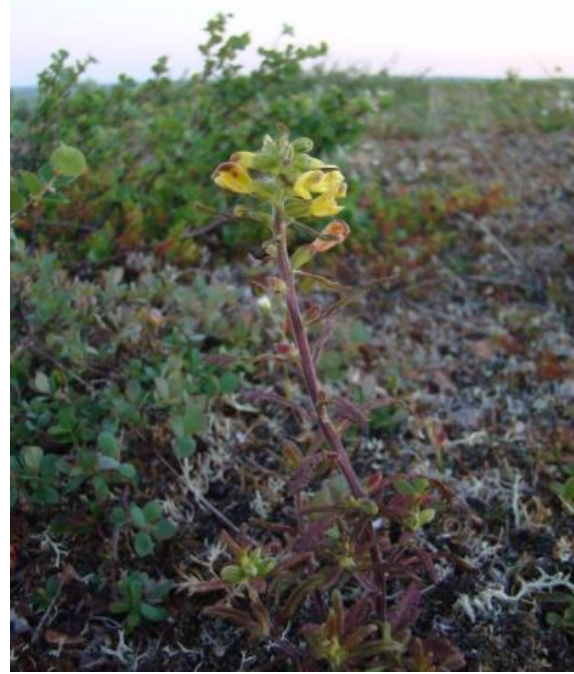

A

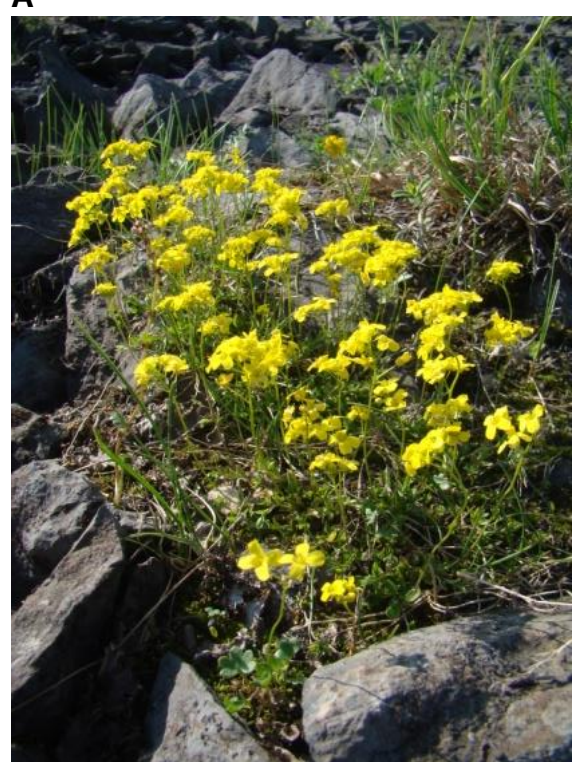

$\Gamma$

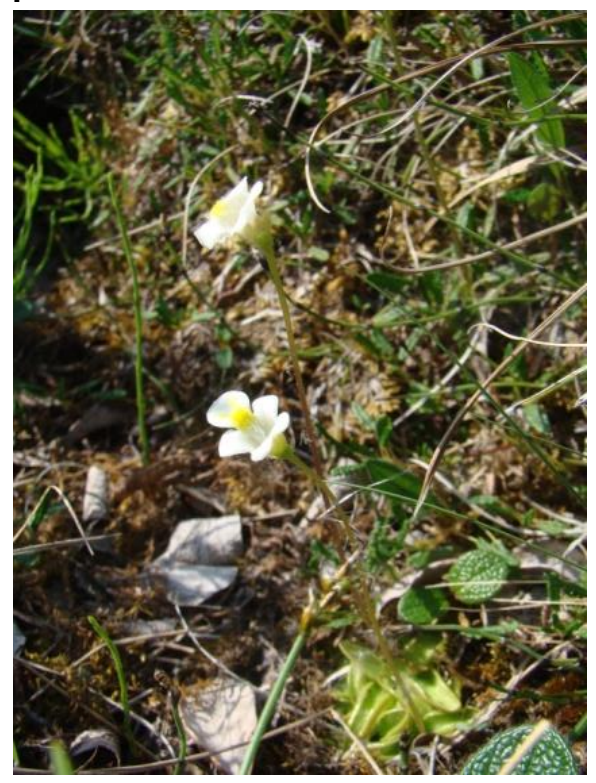

ж

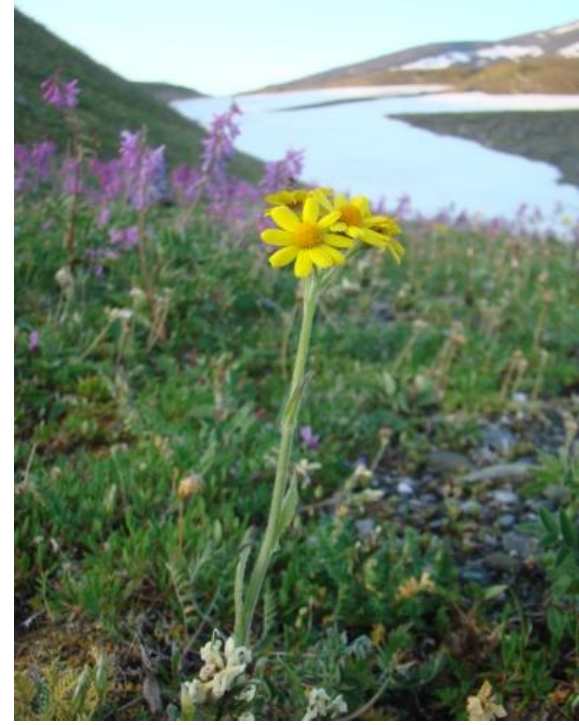

Б

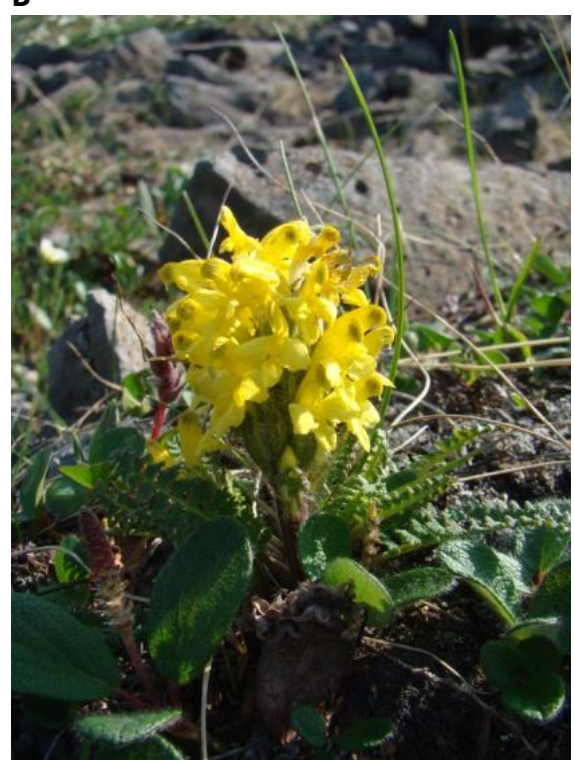

A

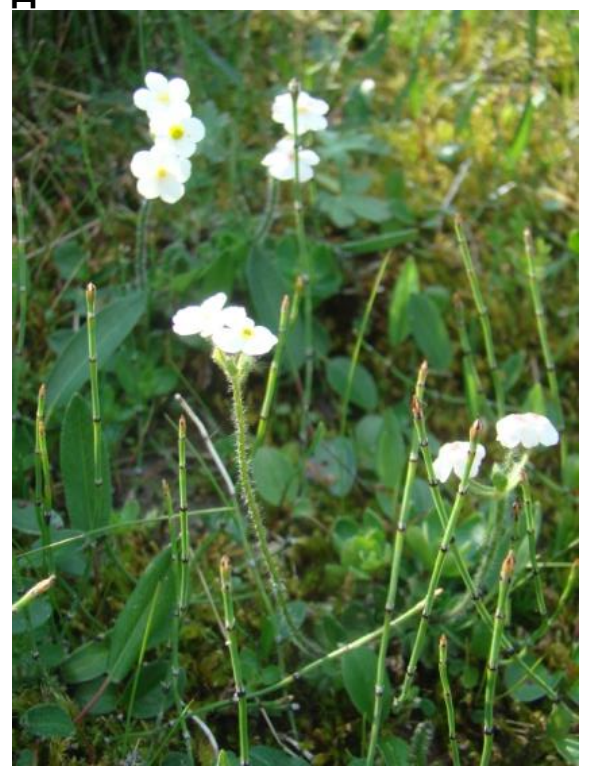

3

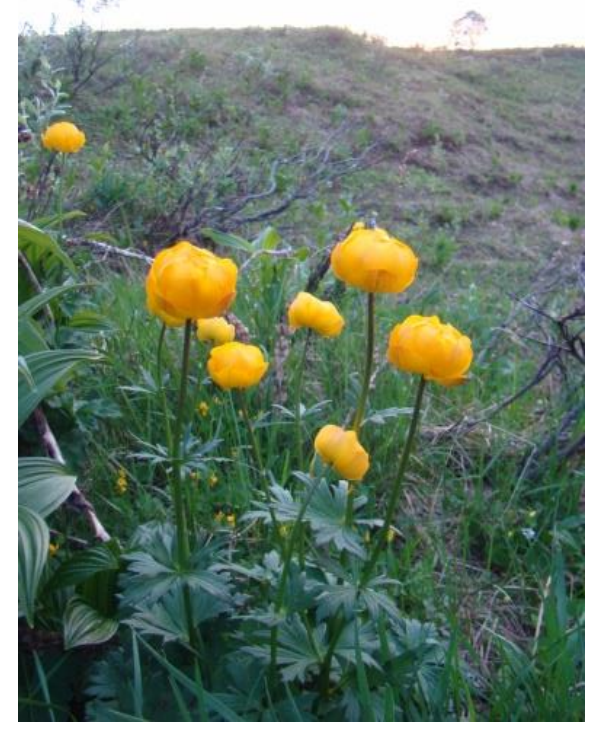

B

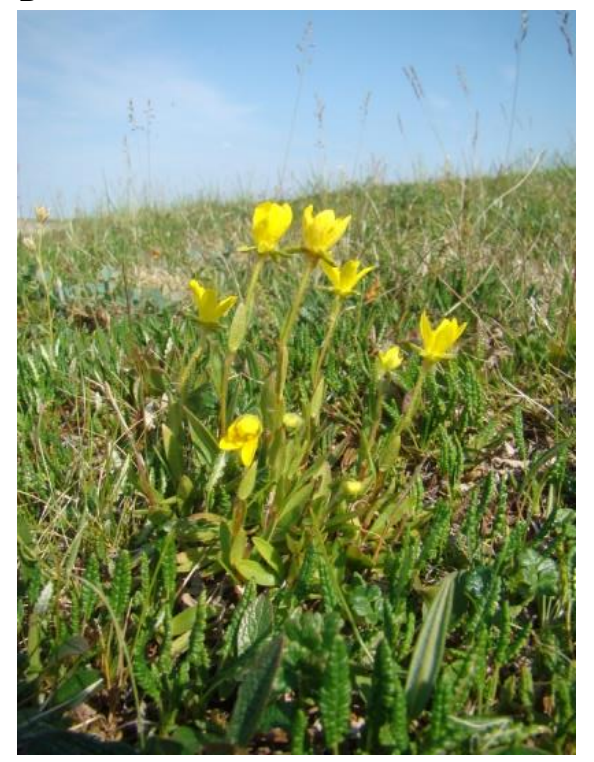

E

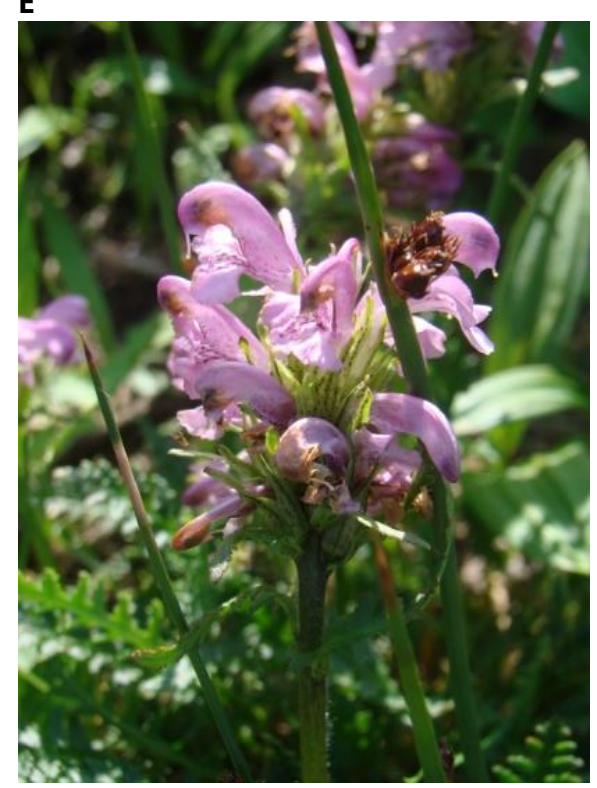

n 


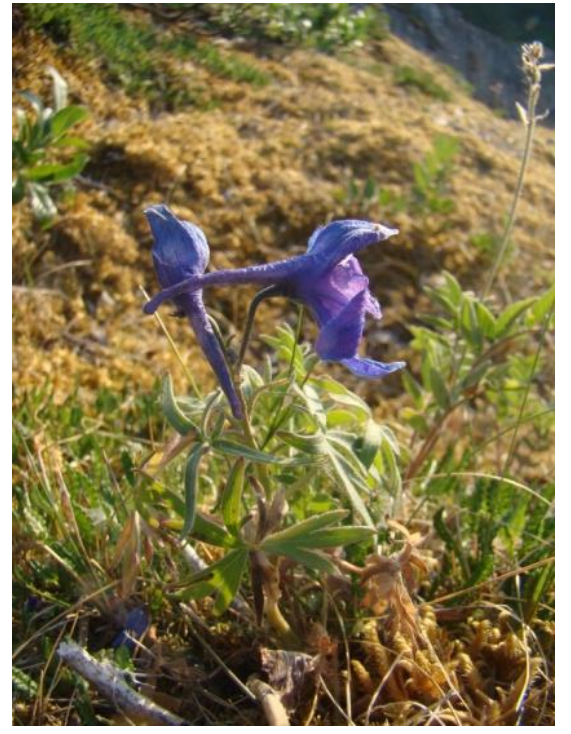

$\mathbf{K}$

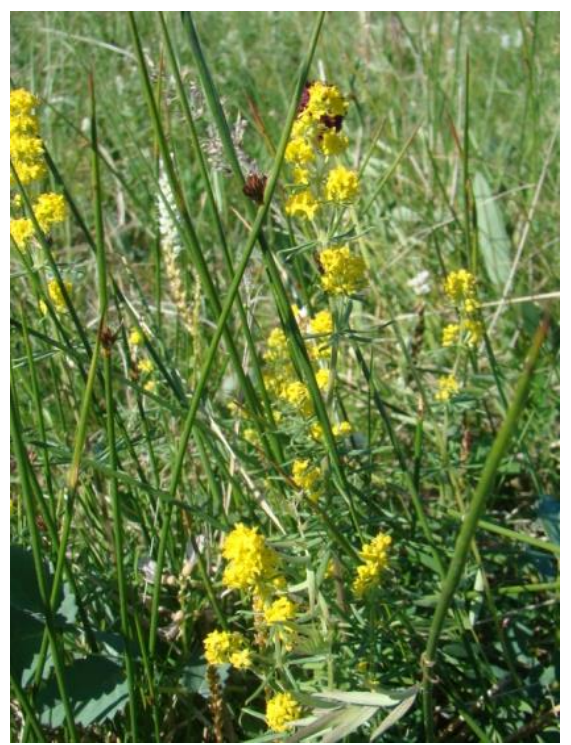

H

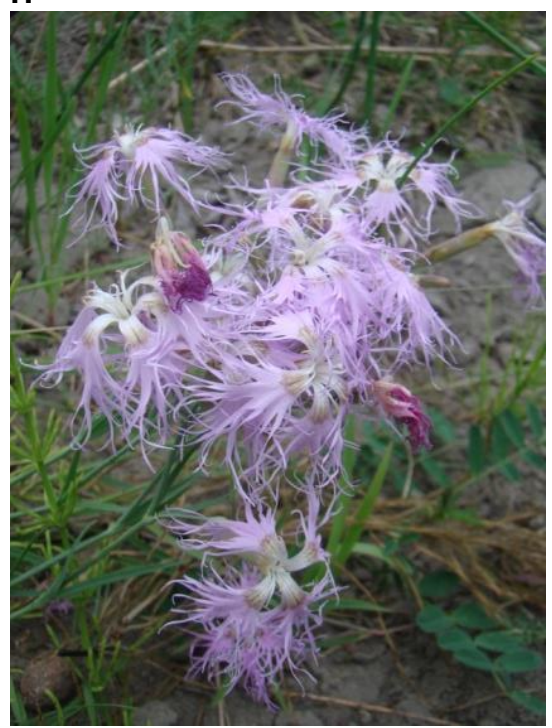

$\mathbf{P}$

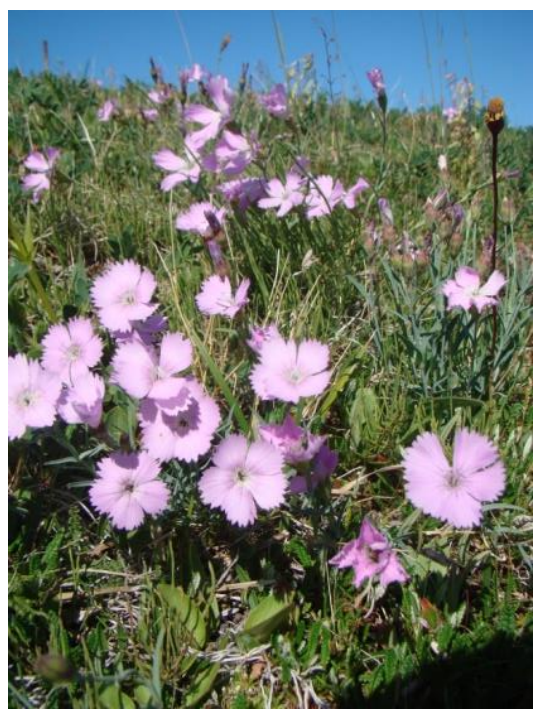

л

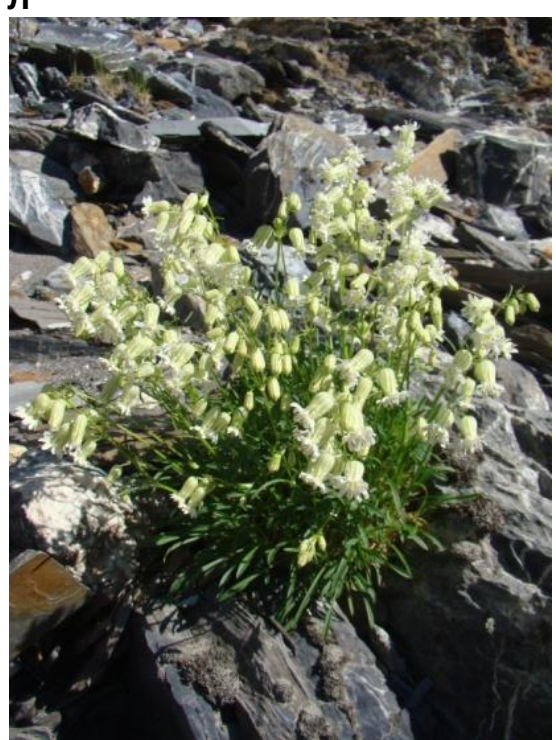

0

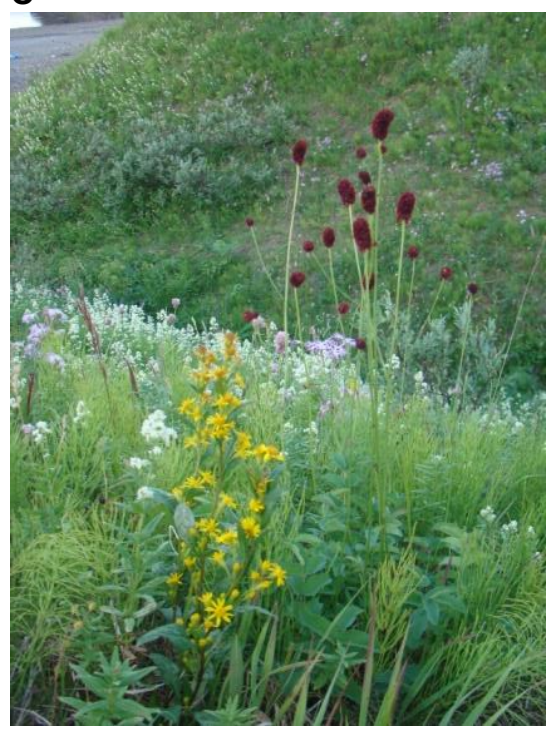

C

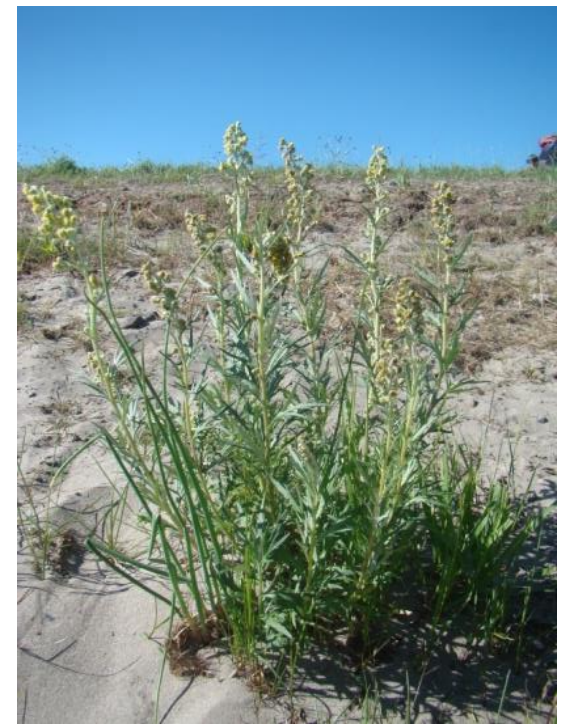

$\mathbf{M}$

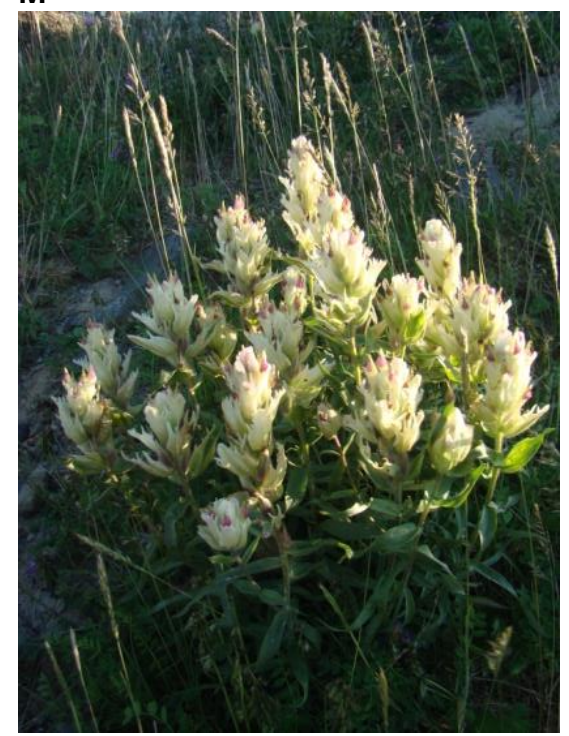

$\Pi$

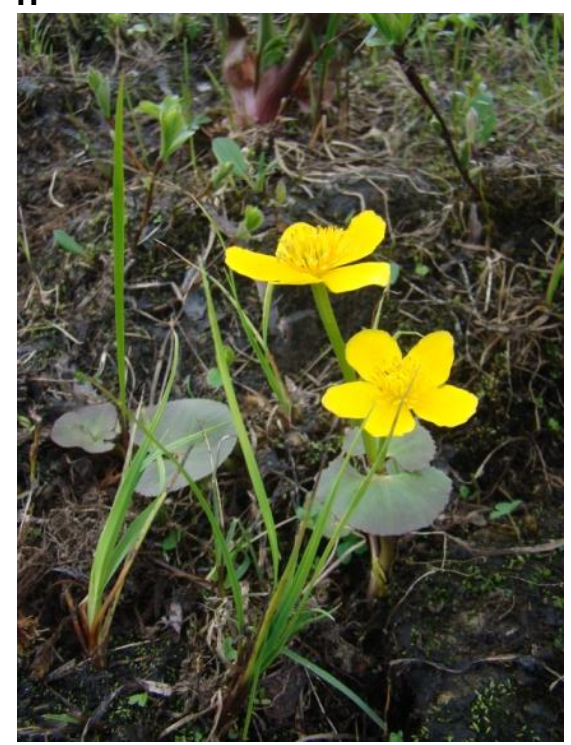

$\mathbf{T}$

Рис. 4. Избранные представители местной флоры: А - Pedicularis labradorica, Б - Senecio integrifolius, В - Trollius apertus, Г - Draba glacialis, Д - Pedicularis oederi и Salix reticulata, E - Saxifraga hirculus, Ж - Pinguicula alpine, 3 - Androsace bungeana, $И$ - Pedicularis sudetica, $\mathrm{K}$ - Delphinium middendorfii, Л - Dianthus repens, M - Artemisia norvegica, $\mathrm{H}$ - Galium densiflorum, O - Silene paucifolia, П - Castilleja lapponica, P - Dianthus superbus, С - разнотравный склон с Equisetum arvense, Sanguisorba officinalis, Solidago virgaurea, Galium boreale/septentrionale, T - Caltha arctica. 


\section{Salicaceae Mirbel}

13. Salix glauca L., 1753, Sp. PI. 2: 1019; Опред. высш. раст. Коми АССР, 1962: 145; Скворцов, 1966, в Арктич. фл. СССР, 5: 68; Скворцов, 1976, во Фл. северо-вост. Европ. ч. СССР, 2: 145; Ребристая, 1977, Фл. востока Большезем. тундры: 71; Раст. покр. и раст. ресурсы Пол. Урала, 2006: 75; Мартыненко, Груздев, 2008, Сосуд. раст. респ. Коми: 51.

Один из обычнейших видов разных типов тундр. Образует чистые заросли и растет вместе с другими видами. Встречается также на болотах. (И.А. Савинов, 19.07.2017, МНА). (Ф.С. Леонтьев, 31.07.1936, 01.08.1936, 08.08.1936, 20.08.1936, 23.09.1936, б/даты, МW).

14. S. lanata L., 1753, Sp. PI. 2: 1019; Опред. высш. раст. Коми АССР, 1962: 146; Скворцов, 1966, в Арктич. фл. СССР, 5: 102; Скворцов, 1976, во Фл. северо-вост. Европ. ч. СССР, 2: 152; Ребристая, 1977, Фл. востока Большезем. тундры: 72; Раст. покр. и раст. ресурсы Пол. Урала, 2006: 76; Мартыненко, Груздев, 2008, Сосуд. раст. респ. Коми: 52.

Ивняково-моховые тундры, особенно обильно в долинных сообществах. Один из видов-доминантов. (Ф.С. Леонтьев, 03.08.1936, 16.09.1936, 20.08.1936, 23.09.1936 (det. А.К. Скворцов), б/даты, МW).

15. S. phylicifolia L., 1753, Sp. PI. 2: 1016; Опред. высш. раст. Коми АССР, 1962: 140, 143; Скворцов, 1966, в Арктич. фл. СССР, 5: 95; Скворцов, 1976, во Фл. северо-вост. Европ. ч. СССР, 2: 150; Ребристая, 1977, Фл. востока Большезем. тундры: 72; Раст. покр. и раст. ресурсы Пол. Урала, 2006: 76; Мартыненко, Груздев, 2008, Сосуд. раст. респ. Коми: 52.

Широко распространенный вид, чаще в виде примеси к предыдущим видам. (Ф.С. Леонтьев, 15.08.1936, 20.08.1936, 24.08.1936, 01.09.1936, MW).

16. S. reticulata L., 1753, Sp. PI. 2: 1018-1019; Опред. высш. раст. Коми АССР, 1962: 138; Скворцов, 1966, в Арктич. фл. СССР, 5: 42; Скворцов, 1976, во Фл. северо-вост. Европ. ч. СССР, 2: 143; Ребристая, 1977, Фл. востока Большезем. тундры: 73; Раст. покр. и раст. ресурсы Пол. Урала, 2006: 77; Мартыненко, Груздев, 2008, Сосуд. раст. респ. Коми: 51.

Тундры, снежники, ложбины. Разнотравно-моховые участки в долинах рек. (Ф.С. Леонтьев, 20.08.1936, 24.08.1936, МW). Рис. 4, Д.

\section{Betulaceae S.F. Gray}

17. Betula nana L., 1753, Sp. PI. 2: 983; Опред. высш. раст. Коми АССР, 1962: 151; Черепанов, 1966, в Арктич. фл. СССР, 5: 122; Орлова, 1976, во Фл. северо-вост. Европ. ч. СССР, 2: 155; Ребристая, 1977, Фл. востока Большезем. тундры: 73; Раст. покр. и раст. ресурсы Пол. Урала, 2006: 78; Мартыненко, Груздев, 2008, Сосуд. раст. респ. Коми: 53.

Плакорные тундровые сообщества, на буграх и болотах, в пятнистых кустарничковых тундрах на песчаных субстратах. Широко распространенный вид. Формирует ерниковые сообщества. (Ф.С. Леонтьев, 1936 г., МW).

\section{Polygonaceae Juss.}

18. Bistorta major S.F. Gray, 1821, Nat. Arr. Brit. PI. 2: 267; Опред. высш. раст. Коми АССР, 1962: 159; Раст. покр. и раст. ресурсы Пол. Урала, 2006: 79; Мартыненко, Груздев, 2008, Сосуд. раст. респ. Коми: 56. - Polygonum bistorta L. 1753, Sp. PI. 360; Опред. высш. раст. Коми АССР, 1962: 159; Толмачев, Петровскеий, 1966, в Арктич. фл. СССР, 5: 175; Мартыненко, 1976, во Фл. северо-вост. Европ. ч. СССР, 2: 183; Ребристая, 1977, Фл. востока Большезем. тундры: 75.

Кустарниковые моховые тундры, разнотравные ивняки. Обычно в разнотравных сообществах, на крутых склонах, речных террасах.

19. B. vivipara (L.) S.F. Gray, 1821, Nat. Arr. Brit. PI. 2: 268; Раст. покр. и раст. ресурсы Пол. Урала, 2006: 80; Мартыненко, Груздев, 2008, Сосуд. раст. респ. Коми: 56. - Polygonum viviparum L. 1753, Sp. PI. 360; Опред. высш. раст. Коми АССР, 1962: 159; Толмачев, Петровскеий, 1966, Арктич. фл. СССР, 5: 173; Мартыненко, 1976, во Фл. северовост. Европ. ч. СССР, 2: 183; Ребристая, 1977, Фл. востока Большезем. тундры: 75.

Широко распространен в разных типах тундр, по склонам и террасам. Повсеместно, но чаще в небольшом количестве. (Ф.С. Леонтьев, 01.08.1936, 12.08.1936, МW).

\section{Caryophyllaceae Juss.}

20. Cerastium regelii Ostenf., 1910, Skr. Vidensk.-Selsk. Christiania, Math.-Naturvidensk. Kl.: 10, f. 11; Раст. покр. и раст. ресурсы Пол. Урала, 2006: 84. - Cerastium jenisejense Hult., 1956, Svensk Bot. Tidskr., 50(3): 473-476, pl. IV: 3-5); Толмачев, 1971, в Арктич. фл. СССР, 6: 41; Лащенкова, 1976, во Фл. северо-вост. Европ. ч. СССР, 2: 211; Ребристая, 1977, Фл. востока Большезем. тундры: 77; Раст. покр. и раст. ресурсы Пол. Урала, 2006: 83; Мартыненко, Груздев, 2008, Сосуд. раст. респ. Коми: 61.

Склоны, скалы, галечниковые и песчаные берега, реже в ивняках и на осоковых болотцах. Лужайка у реки ниже водопада Буредан (7 км). (И.А. Савинов, 26.07.2017, МНА). 
21. Minuartia macrocarpa (Pursh) Ostenf., 1920, Meddel. Grønland 37(12): 226; Опред. высш. раст. Коми АССР, 1962: 172; Ребристая, 1971, в Арктич. фл. СССР, 6: 65; Лащенкова, 1976, во Фл. северо-вост. Европ. ч. СССР, 2: 219; Ребристая, 1977, Фл. востока Большезем. тундры: 78; Раст. покр. и раст. ресурсы Пол. Урала, 2006: 86; Мартыненко, Груздев, 2008, Сосуд. раст. респ. Коми: 62.

Пятна голого грунта в тундре, сухие, часто щебнистые склоны. Крутой склон к реке, у устья р. Ладхэйяхи. Красная книга НАО, статус 3 (2006)!

22. Silene acaulis (L.) Jacq., 1762, Enum. Stirp. Vindob. 78: 242; Опред. высш. раст. Коми ACCP, 1962: 174; Юрцев, 1971, в Арктич. фл. СССР, 6: 96; Лащенкова, 1976, во Фл. северо-вост. Европ. ч. СССР, 2: 232; Ребристая, 1977, Фл. востока Большезем. тундры: 78; Раст. покр. и раст. ресурсы Пол. Урала, 2006: 87; Мартыненко, Груздев, 2008, Сосуд. раст. респ. Коми: 64.

Разнотравно-моховые тундры у снежников, пятнистые кустарничковых тундры, береговые откосы. На склонах коренного берега р. Лядхэйяхи, притока р. Кары. Изредка. (И.А. Савинов, 19.07.2017, МНА). (Ф.С. Леонтьев, 20.08.1936, MW).

23. S. paucifolia Ledeb., 1842, Fl. Ross. 1(2): 306; Опред. высш. раст. Коми ACCP, 1962: 176; Юрцев, 1971, в Арктич. фл. СССР, 6: 88; Лащенкова, 1976, во Фл. северо-вост. Европ. ч. СССР, 2: 231; Ребристая, 1977, Фл. востока Большезем. тундры: 78; Раст. покр. и раст. ресурсы Пол. Урала, 2006: 88; Мартыненко, Груздев, 2008, Сосуд. раст. респ. Коми: 64.

Сухие щебнистые склоны, галечники рек, пупыри, разные типы тундр. На камнях и приречных склонах в долине р. Кара (включая приуральскую часть), изредка. (И.А. Савинов, 26.07.2017, МНА). Красная книга НАО, статус 3 (2006), Красная книга Республики Коми, статус 3 (2009)! Рис. 4, 0.

24. Dianthus repens Willd., 1799, Sp. PI. 2(1): 681-682; Опред. высш. раст. Коми ACСР, 1962: 178; Петровский, 1971, в Арктич. Фл. СССР, 6: 119; Лащенкова, 1976, во Фл. северо-вост. Европ. ч. СССР, 2: 241; Ребристая, 1977, Фл. востока Большезем. тундры: 79; Раст. покр. и раст. ресурсы Пол. Урала, 2006: 84; Мартыненко, Груздев, 2008, Сосуд. раст. респ. Коми: 65.

Песчаные склоны, щебнистые откосы. В массе на береговых песчаных склонах и откосах близ водопада Буредан. Красная книга Республики Коми, статус 3 (2009)! (Ф.С. Леонтьев, 07.08.1936, МW). Рис. 4, л.

25. D. superbus L., 1755, Fl. Suec. (ed. 2): 146; Опред. высш. раст. Коми ACCP, 1962: 178; Петровский, 1971, в Арктич. фл. СССР, 6: 122; Лащенкова, 1976, во Фл. северо-вост. Европ. ч. СССР, 2: 242; Ребристая, 1977, Фл. востока Большезем. тундры: 79; Раст. покр. и раст. ресурсы Пол. Урала, 2006: 84; Мартыненко, Груздев, 2008, Сосуд. раст. респ. Коми: 66.

Разнотравные береговые склоны. По склонам близ устья р. Силовояхи среди разнотравья, в массе. (И.А. Савинов, 28.07.2017, МНА). Рис. 4, P.

\section{Ranunculaceae Juss.}

26. Caltha arctica R.Br., 1823, Chlor. Melvill.: 7; Толмачев, 1971, в Арктич. фл. СCCP, 6: 129; Мартыненко, 1976, во Фл. северо-вост. Европ. ч. СССР, 3: 13; Ребристая, 1977, Фл. востока Большезем. тундры: 79; Раст. покр. и раст. ресурсы Пол. Урала, 2006: 91.

Берега ручьев, близ стока снежных вод, замоховелые галечники. Отмечена нами в нижнем течении p. Хальмерью (около 20 км выше устья, близ водопада), сыроватая лужайка у левого берега реки. Небольшое число особей. По данным О.В. Ребристой (1977), вид встречается исключительно в районе хребта Пай-Хой. Таким образом, наша точка находится примерно в 60 км южнее указаний предыдущего автора. В силу ее изолированного положения от основной части ареала обнаруженная популяция требует охраны. Рис. 4, т.

27. C. palustris L., 1753, Sp. PI. 1: 558; Опред. высш. раст. Коми АССР, 1962: 181; Толмачев, 1971, в Арктич. фл. СССР, 6: 128; Мартыненко, 1976, во Фл. северо-вост. Европ. ч. СССР, 3: 13; Ребристая, 1977, Фл. востока Большезем. тундры: 79; Раст. покр. и раст. ресурсы Пол. Урала, 2006: 91; Мартыненко, Груздев, 2008, Сосуд. раст. респ. Коми: 67.

Берега рек и ручьев (иногда на мелководье), сырые заболоченные ивняки, сырые осоковые тундры, мочажины болот. Обычный вид.

28. Trollius apertus Perf. ex Igoschina, 1968, Bot. J. URSS 53: 793; Опред. высш. раст. Коми ACCP, 1962: 182 (as T. europaeus var. apertus Perf.); Толмачев, 1971, в Арктич. фл. СССР, 6: 134; Мартыненко, 1976, во Фл. северо-вост. Европ. Ч. СССР, 3: 14; Ребристая, 1977, Фл. востока Большезем. тундры: 79; Раст. покр. и раст. ресурсы Пол. Урала, 2006: 94; Мартыненко, Груздев, 2008, Сосуд. раст. респ. Коми: 71. Рис. 4, В; 
29. T. europaeus L., 1753, Sp. PI. 1: 556-557; Опред. Высш. раст. Коми АССР, 1962: 182; Толмачев, 1971 , в Арктич. фл. СССР, 6: 134; Мартыненко, 1976, во Фл. северо-вост. Европ. ч. СССР, 3: 14; Ребристая, 1977, Фл. востока Большезем. тундры: 80; Мартыненко, Груздев, 2008, Сосуд. раст. респ. Коми: 71.

Разнотравные луга, среди кустарника, лужайки около снежников, приречные лужайки. Виды купальниц не различимы по вегетативным признакам (см., например, Скворцов, 2000). По литературным данным (Растительный покров..., 2006), для Полярного Урала приводится только один гибридный вид - T. apertus Perf. ex Igoschina (очень обычен), с уклонениями к T. europaea (в районе г. Воркуты) и к T. asiaticus L. (на восточных склонах Полярного Урала, близ ст. Собь). Следуя диагностическим признакам во «Флоре Сибири» (Фризен, 1993), особи с более или менее шаровидными закрытыми цветками и сильно вогнутыми чашелистиками следует относить к T. еuropaеa, а со слабо раскрытыми цветками и вогнутыми чашелистиками - к T. apertus (у T. asiaticus цветок широко раскрытый). Встреченные нами цветущие экземпляры соответствуют обоим видам - T. apertus и T. europaeus. T. apertus в Красной книге НАО, статус 3 (2006) и Красной книге Республики Коми, статус 4 (2009)!

30. Delphinium elatum L., 1753, Sp. PI. 1: 531; Опред. высш. раст. Коми АССР, 1962: 182; Юрцев, 1971 , в Арктич. фл. СССР, 6: 152; Мартыненко, 1976, во Фл. северо-вост. Европ. ч. СССР, 3: 16; Ребристая, 1977, Фл. востока Большезем. тундры: 80; Раст. покр. и раст. ресурсы Пол. Урала, 2006: 91; Мартыненко, Груздев, 2008, Сосуд. раст. респ. Коми: 67.

Разнотравные береговые склоны, ивняки, ерниковые разнотравно-моховые тундры. Склоны к реке, устье р. Силовояхи. (Ф.С. Леонтьев, 20.07.1936, МW).

31. D. middendorffii Trautv., 1847-1864, Middend. Sibir. Reise i. Bot. (Fl. Taimyr.): 63; Юрцев, 1971, в Арктич. фл. СССР, 6: 148; Мартыненко, 1976, во Фл. северо-вост. Европ. ч. СССР, 3: 16; Ребристая, 1977, Фл. востока Большезем. тундры: 80; Раст. покр. и раст. ресурсы Пол. Урала, 2006: 91; Мартыненко, Груздев, 2008, Сосуд. раст. респ. Коми: 67. - D. brachycentrum Ledeb., 1841, Fl. Ross. 1(1): 60-61.

Песчаные склоны, выходы известняка, доломитовые каньоны в долинах рек. Редко, доломитовый каньон р. Нерусавэйяхи, близ ее впадения в р. Кару, мшистый каменистый склон. (И.А. Савинов, 24.07.2017, МНА). Также встречен на пупыре близ устья р. Силовояхи, среди разнотравья. Красная книга НАО, статус 3 (2006), Красная книга Республики Коми, статус 4 (2009)! Рис. 4, К.

32. Aconitum septentrionale Koelle, 1787, Spic. Observ. Aconit. 22; Юрцев, 1971, в Арктич. фл. СССР, 6: 156; Ребристая, 1977, Фл. востока Большезем. тундры: 80; Раст. покр. и раст. ресурсы Пол. Урала, 2006: 90; Мартыненко, Груздев, 2008, Сосуд. раст. респ. Коми: 66. - A. excelsum Rchb., Опред. высш. раст. Коми АССР, 1962: 182; Мартыненко, 1976, во Фл. северо-вост. Европ. ч. СССР, 3: 17.

В ивняках по берегам рек, изредка.

33. Ranunculus pedatifidus var. affinis (R. Br.) L.D. Benson, 1954, Amer. Midl. Naturalist 52: 355. - Ranunculus affinis R.Br., 1823, J. Voy. N.-W. Passage, Bot. 7; Опред. высш. раст. Коми АCCP, 1962: 187; Толмачев, 1971, в Арктич. фл. СССР, 6: 212; Мартыненко, 1976, во Фл. северо-вост. Европ. ч. СССР, 3: 32; Ребристая, 1977, Фл. востока Большезем. тундры: 80.

Сыроватые участки рек и ручьев, редко! Встречен на правом берегу р. Кара близ устья р. Нярмаяхи, у галечника.

34. R. reptans L., 1753, Sp. PI. 1: 549; Опред. высш. раст. Коми АССР, 1962: 186; Толмачев, 1971, в Арктич. фл. СССР, 6: 194; Мартыненко, 1976, во Фл. северо-вост. Европ. ч. СССР, 3: 31; Ребристая, 1977, Фл. востока Большезем. тундры: 82; Раст. покр. и раст. ресурсы Пол. Урала, 2006: 93; Мартыненко, Груздев, 2008, Сосуд. раст. респ. Коми: 70.

Песчаные и илистые отмели, увлажненные лужайки в тундре. Правый берег р. Кара близ устья р. Нерусавэйяха, сильно увлажненная лужайка среди тундры. (И.А. Савинов, 24.07.2017, МНА). Ранее (Ребристая, 1977) не был указан для долины р. Кары.

35. Thalictrum minus L. Опред. высш. раст. Коми ACCP, 1962: 190; Мартыненко, 1976, во Фл. северо-вост. Европ. 4. СССР, 3: 38; Мартыненко, Груздев, 2008, Сосуд. раст. респ. Коми: 70. - T. minus subsp. kemense (Fries) M.-Caj., 1906, Suom. Kasvio 276; Петровский, 1971, в Арктич. фл. СССР, 6: 228; Ребристая, 1977, Фл. востока Большезем. тундры: 82; Раст. покр. и раст. ресурсы Пол. Урала, 2006: 94. - T. minus var. kemense (Fr.) Trel., 1888, Proc. Boston Soc. Nat. Hist. 23: 300; T. kemense (Fries) Koch, 1817, Fl. Hall. 95.

В ивняках, по береговым склонам. На разнотравных луговых склонах к реке. Изредка, встречен у устья р. Ладхэйяхи.

\section{Papaveraceae A.L. Juss.}

36. Papaver lapponicum (Tolm.) Nordh., 1931, Bergens Mus. Årbok 2: 45; P. lapponicum subsp. jugoricum (Tolm.) Tolm., Опред. высш. раст. Коми АССР, 1962: 191; Толмачев, 1975, в Арктич. фл. СССР, 7: 18; Толмачев, Мартыненко, 
1976, во Фл. северо-вост. Европ. ч. СССР, 3: 42; Ребристая, 1977, Фл. востока Большезем. тундры: 82; Раст. покр. и раст. ресурсы Пол. Урала, 2006: 95; Мартыненко, Груздев, 2008, Сосуд. раст. респ. Коми: 72. Papaver jugoricum Stankov, 1949, Syst. Classif. Vasc. PI. Eur. Russ. 134.

Пятнистые дриадовые тундры, на щебнистых субстратах, кустарничково-лишайниковые каменистые тундры, на обдуваемых участках. На скалах в долине р. Кары, изредка. Правый берег р. Кара, каньон «малого» порога, за 3 км до устья р. Брусьяха, на скалах. (И.А. Савинов, 26.07.2017, МНА). (Ф.С. Леонтьев, 24.08.1936, МW). Красная книга Республики Коми, статус 2 (2009)!

\section{Brassicaceae Burnett (Cruciferae Juss.)}

37. Draba glacialis Adams, 1817, Mém. Soc. Imp. Naturalistes Moscou 5: 106-107; Опред. высш. раст. Коми АССР, 1962: 206; Толмачев, 1975, в Арктич. фл. СССР, 7: 128; Толмачев, 1976, во Фл. северо-вост. Европ. ч. СССР, 3: 71; Ребристая, 1977, Фл. востока Большезем. тундры: 84; Раст. покр. и раст. ресурсы Пол. Урала, 2006: 99; Мартыненко, Груздев, 2008, Сосуд. раст. респ. Коми: 76.

Скальные выходы и осыпи, сухие пятнистые тундры. Каменистый склон к реке, среди разнотравной дриадово-моховой тундры. (И.А. Савинов, 19.07.2017, МНА). (Ф.С. Леонтьев, 21.09.1936, МW). Красная книга НАО, статус 3 (2006), Красная книга Республики Коми, статус 4 (2009)! Рис. 4, Г.

\section{Crassulaceae DC}

38. Rhodiola quadrifida (Pall.) Fisch. et Mey., 1841, in Schrenk, Enum. PI. Nov. 1: 69; Опред. высш. раст. Коми АССР, 1962: 211; Мартыненко, 1976, во Фл. северо-вост. Европ. ч. СССР, 3: 88; Ребристая, 1977, Фл. востока Большезем. тундры: 85; Петровский, 1984, в Арктич. фл. СССР, 9(1): 11; Раст. покр. и раст. ресурсы Пол. Урала, 2006: 101; Мартыненко, Груздев, 2008, Сосуд. раст. респ. Коми: 79.

Щебнистые склоны, каменистые выходы, пятнистые тундры, на сухих местах, пупырях. (Ф.С. Леонтьев, 15.08.1936, 3.09.1936, МW). В Красной книге ЯНАО, статус 3 (2010), Красной книге НАО, статус 3 (2006), Красной книге Республики Коми, статус 2 (2009)!

\section{Parnassiaceae S.F. Gray}

39. Parnassia palustris L., 1753, Sp. PI. 1: 273; Опред. высш. раст. Коми АССР, 1962: 212; Толмачев, Мартыненко, 1976, во Фл. северо-вост. Европ. ч. СССР, 3: 100; Ребристая, 1977, Фл. востока Большезем. тундры: 87; Тараскина, 1984, в Арктич. фл. СССР, 9(1): 19; Раст. покр. и раст. ресурсы Пол. Урала, 2006: 104, 105; Мартыненко, Груздев, 2008, Сосуд. раст. респ. Коми: 79.

Разнотравные береговые склоны, сырые луговины, у снежников. Обычно на мшистых участках склонов. (Ф.С. Леонтьев, 10.08.1936, 19.08.1936, MW). Преобладает северная раса, принимаемая специалистами как P. palustris subsp. neogaea (Fern.) Hult., 1945, Fl. Alaska Yukon 5: 956.

\section{Saxifragaceae Juss.}

40. Saxifraga hirculus L., 1753, Sp. PI. 1: 402-403; Опред. высш. раст. Коми АССР, 1962: 213; Толмачев, Мартыненко, 1976, во Фл. северо-вост. Европ. ч. СССР, 3: 95; Ребристая, 1977, Фл. востока Большезем. тундры: 86; Ребристая, Юрцев, 1984, в Арктич. фл. СССР, 9(1): 41; Раст. покр. и раст. ресурсы Пол. Урала, 2006: 103; Мартыненко, Груздев, 2008, Сосуд. раст. респ. Коми: 80.

Разнотравно-моховые тундры, луговины у ручьев. Один из самых обычных видов камнеломок в Карской тундре. Рис. 4, E.

41. Chrysosplenium alternifolium L., 1753, Sp. PI. 398; Опред. высш. раст. Коми АССР, 1962: 212; Толмачев, Мартыненко, 1976, во Фл. северо-вост. Европ. ч. СССР, 3: 99; Ребристая, 1977, Фл. востока Большезем. тундры: 87; Тараскина, 1984, в Арктич. фл. СССР, 9(1): 90; Раст. покр. и раст. ресурсы Пол. Урала, 2006: 102; Мартыненко, Груздев, 2008, Сосуд. раст. респ. Коми: 79.

Сырые тундры, ивняки, окраины осоковых болот, луговины и моховые подушки в долинах рек и ручьев, берега водоемов, часто. (Ф.С. Леонтьев, 13.08.1936, 24.08.1936, МW).

\section{Rosaceae Juss.}

42. Alchemilla vulgaris L. S.I.

Часто в разнотравных группировках по долинам рек, в ивняках.

Примечание. A. vulgaris L. S.I. - это апомиктический комплекс, состоящий из большого числа мелких видов, для надежного определения которых требуются массовые неоднократные сборы материала в природе (Скворцов, 2000). 
Savinov, I. A. New materials for flora of Kara river.... Acta Biologica Sibirica, 2018, 4(1), 52-72

43. Geum rivale L., 1753, Sp. PI. 1: 501; Опред. высш. раст. Коми АССР, 1962: 225; Кобелева, 1976, во Фл. северовост. Европ. ч. СССР, 3: 131; Ребристая, 1977, Фл. востока Большезем. тундры: 89; Ребристая, 1984, в Арктич. фл. СССР, 9(1): 249; Раст. покр. и раст. ресурсы Пол. Урала, 2006: 107; Мартыненко, Груздев, 2008, Сосуд. раст. респ. Коми: 84.

Заросли сырых ивняков, осоковые западины, вдоль водотоков по склонам, преимущественно в приуральской части.

44. Rubus arcticus L., 1753, Sp. PI. 1: 494; Опред. высш. раст. Коми АССР, 1962: 220; Кобелева, 1976, во Фл. северовост. Европ. ч. СССР, 3: 117; Ребристая, 1977, Фл. востока Большезем. тундры: 87; Гладкова, 1984, в Арктич. фл. СССР, 9(1): 125; Раст. покр. и раст. ресурсы Пол. Урала, 2006: 109; Мартыненко, Груздев, 2008, Сосуд. раст. респ. Коми: 82.

Сырые ивняки и тундры. Часто в разнотравных группировках, среди кустарников.

45. R. chamaemorus L., 1753, Sp. PI. 1: 494; Опред. высш. раст. Коми АССР, 1962: 221; Кобелева, 1976 , во Фл. северо-вост. Европ. ч. СССР, 3: 116; Ребристая, 1977, Фл. востока Большезем. тундры: 88; Гладкова, 1984, в Арктич. фл. СССР, 9(1): 122; Раст. покр. и раст. ресурсы Пол. Урала, 2006: 109; Мартыненко, Груздев, 2008, Сосуд. раст. респ. Коми: 82.

Кочки кустарниковых заболоченных тундр, торфяные бугры и валики болот, сырые ивняки и ерники, моховые участки. Изредка. (Ф.С. Леонтьев, 03.08.1936, МW).

46. Comarum palustre L., 1753, Sp. PI. 1: 502; Опред. высш. раст. Коми АССР, 1962: 221; Кобелева, 1976 , во Фл. северо-вост. Европ. ч. СССР, 3: 121; Ребристая, 1977, Фл. востока Большезем. тундры: 88; Гладкова, 1984, в Арктич. фл. СССР, 9(1): 134; Раст. покр. и раст. ресурсы Пол. Урала, 2006: 106; Мартыненко, Груздев, 2008, Сосуд. раст. респ. Коми: 82.

Сырые ивняки, осоковые болота, берега водоемов, часто. (Ф.С. Леонтьев, 28.08.1936, б/даты, MW).

47. Dryas octopetala L., 1753, Sp. PI. 1: 501-502; Опред. высш. раст. Коми АССР, 1962: 225; Кобелева, 1976, во Фл. северо-вост. Европ. ч. СССР, 3: 133; Ребристая, 1977, Фл. востока Большезем. тундры: 89; Юрцев, 1984, в Арктич. фл. СССР, 9(1): 262; Мартыненко, Груздев, 2008, Сосуд. раст. респ. Коми: 84.

Щебнистые склоны, сухие бугры, пупыри, дриадовые тундры. Обычный вид-ценозообразователь. (Ф.С. Леонтьев, 1936 г., MW).

48. Sanguisorba officinalis L., 1753, Sp. PI. 1: 116; Опред. высш. раст. Коми АССР, 1962: 228; Кобелева, 1976, во Фл. северо-вост. Европ. ч. СССР, 3: 145; Ребристая, 1977, Фл. востока Большезем. тундры: 90; Петровский, 1984, в Арктич. фл. СССР, 9(1): 302; Раст. покр. и раст. ресурсы Пол. Урала, 2006: 109; Мартыненко, Груздев, 2008, Сосуд. раст. респ. Коми: 87.

Обычно на приречных склонах, ивняках, галечниках рек, особенно у устья р. Силовояхи. Рис. 4, С.

49. Rosa acicularis Lindl., 1820, Ros. Monogr. 44-45, pl. 8; Опред. высш. раст. Коми АССР, 1962: 229; Кобелева, 1976, во Фл. северо-вост. Европ. ч. СССР, 3: 147; Ребристая, 1977, Фл. востока Большезем. тундры: 90; Бузунова, 1984, в Арктич. фл. СССР, 9(1): 303; Раст. покр. и раст. ресурсы Пол. Урала, 2006: 109; Мартыненко, Груздев, 2008, Сосуд. раст. респ. Коми: 87.

Изредка вдоль всей долины р. Кары по береговым склонам, ивняковым и ерниковым тундрам.

\section{Fabaceae Lindl. (Leguminosae Juss.)}

50. Vicia cracca L., 1753, Sp. PI. 2: 735; Опред. высш. раст. Коми АССР, 1962: 238; Кобелева, 1976, во Фл. северовост. Европ. ч. СССР, 3: 174; Ребристая, 1977, Фл. востока Большезем. тундры: 91; Коробков, 1986, в Арктич. фл. СССР, 9(2): 164; Раст. покр. и раст. ресурсы Пол. Урала, 2006: 113; Мартыненко, Груздев, 2008, Сосуд. раст. респ. Коми: 91.

Среди разнотравья в зарослях кустарников по склонам к реке Кара. (И.А. Савинов, 18.07.2017, 24.07.2017, МНА). (Ф.С. Леонтьев, 03.08.1936, 08.08.1936, б/даты, МW). Здесь находятся наиболее северные местонахождения вида.

51. Hedysarum arcticum B. Fedtsch., 1939, Sborn. President. Akad. Nauk V.L. Komarov 735; Опред. высш. раст. Коми АССР, 1962: 236; Кобелева, 1976, во Фл. северо-вост. Европ. ч. СССР, 3: 170; Ребристая, 1977, Фл. востока Большезем. тундры: 91; Раст. покр. и раст. ресурсы Пол. Урала, 2006: 112; Мартыненко, Груздев, 2008, Сосуд. раст. респ. Коми: 88. - Н. hedysaroides subsp. arcticum (В. Fedtsch.) P.W. Ball, Юрцев, 1986, в Арктич. фл. СССР, 9(2): 157.

Обычно на склонах, вершинах бугров, в разнотравно-дриадовых тундрах. В массе по склонам хребта Оченырд (Полярный Урал), склонам к долине р. Кары. (Ф.С. Леонтьев, 03.08.1936, МW). 
52. Astragalus subpolaris Boriss. et Schischk., 1946, Flora URSS 12: 44; Опред. высш. раст. Коми ACCP, 1962: 235; Кобелева, 1976, во Фл. северо-вост. Европ. ч. СССР, 3: 167; Ребристая, 1977, Фл. востока Большезем. тундры: 90; Раст. покр. и раст. ресурсы Пол. Урала, 2006: 111; Мартыненко, Груздев, 2008, Сосуд. раст. респ. Коми: 87. - A. alpinus subsp. arcticus Lindm., Юрцев, 1986, в Арктич. фл. ССCP, 9(2): 38.

Обычно по склонам, в луговых сообществах, разных типах тундры. (Ф.С. Леонтьев, 07.08.1936, MW).

53. Oxytropis sordida (Willd.) Pers., 1807, Syn. PI. 2(2): 332; Опред. высш. раст. Коми АCCP, 1962: 236; Кобелева, 1976, во Фл. северо-вост. Европ. Ч. СССР, 3: 169; Ребристая, 1977, Фл. востока Большезем. тундры: 90; Юрцев, 1986, в Арктич. фл. СССР, 9(2): 109; Раст. покр. и раст. ресурсы Пол. Урала, 2006: 113; Мартыненко, Груздев, 2008, Сосуд. раст. респ. Коми: 89.

Пятнистые тундры, разнотравье по берегам рек, галечники рек, часто. (Ф.С. Леонтьев, 07.08.1936, МW).

\section{Geraniaceae Juss.}

54. Geranium albiflorum Ledeb., 1829, Ic. Pl. Fl. Ross. 1: 6; Опред. высш. раст. Коми ACCP, 1962: 240; Мартыненко, 1976, во Фл. северо-вост. Европ. ч. СССР, 2: 183; Ребристая, 1977, Фл. востока Большезем. тундры: 91; Ребристая, 1980, в Арктич. фл. СССР, 8: 9.

Разнотравные ивняки, сыроватые луга, часто. (Ф.С. Леонтьев, 1936 г., МW).

\section{Empetraceae Lindl.}

55. Empetrum hermaphroditum Hagerup., 1927, Dansk Bot. Ark. 5(2): 14-17, f. 4c,e, 5; Опред. высш. раст. Коми АССР, 1962: 243; Мартыненко, 1976, во Фл. северо-вост. Европ. ч. СССР, 3: 192; Ребристая, 1977, Фл. востока Большезем. тундры: 91; Цвелев, 1980, в Арктич. фл. СССР, 8: 27; Раст. покр. и раст. ресурсы Пол. Урала, 2006: 115; Мартыненко, Груздев, 2008, Сосуд. раст. респ. Коми: 101.

Разные типы тундр, на песчаных и щебнистых открытых участках. Обычно.

\section{Violaceae Batsch}

56. Viola epipsiloides Löve et D. Löve, 1975[1976], Bot. Not. 128(4): 516; Цвелев, 1980, в Арктич. фл. СССР, 8: 35; Раст. покр. и раст. ресурсы Пол. Урала, 2006: 116.

У подножья склонов коренного берега р. Лядхэйяхи, притока р. Кары, по сырым местообитаниям. Изредка. Вид не упомянут в сводке О.В. Ребристой (1977).

\section{Onagraceae Juss.}

57. Epilobium anagallidifolium Lam., 1786, Encycl. 2(1): 376; Опред. высш. раст. Коми ACCP, 1962: 252; Ребристая, 1977, Фл. востока Большезем. тундры: 92. - E. alpinum L., Скворцов, 1980, в Арктич. фл. СССР, 8: 49; Раст. покр. и раст. ресурсы Пол. Урала, 2006: 117.

Моховины у ручьев, отмели рек, глинистые пятна в дриадовых тундрах. Крутой склон у устья р. Ладхъйяхи. (И.А. Савинов, 19.07.2017, МНА). (Ф.С. Леонтьев, 1936 г., МW).

58. Chamaenerion angustifolium (L.) Scop., 1771, Fl. Carniol. (ed. 2) 1: 271; Опред. высш. раст. Коми ACCP, 1962: 250; Скворцов, 1976, во Фл. северо-вост. Европ. ч. СССР, 3: 217; Ребристая, 1977, Фл. востока Большезем. тундры: 92; Скворцов, 1980, в Арктич. фл. СССР, 8: 52; Раст. покр. и раст. ресурсы Пол. Урала, 2006: 116; Мартыненко, Груздев, 2008, Сосуд. раст. респ. Коми: 96.

Изредка по речным склонам, песчаным буграм, чаще между рр. Брусьяхи и Силоваяхи. Также встречается в массе вдоль автомобильных и вездеходных дорог в тундре, в заброшенном пос. Хальмер-Ю.

59. Ch. latifolium (L.) Sweet, 1830, Hort. Brit., ed. 2: 198; Опред. высш. раст. Коми АССР, 1962: 250; Скворцов, 1976, во Фл. северо-вост. Европ. Ч. СCCP, 3: 217; Ребристая, 1977, Фл. востока Большезем. тундры: 92 (as Ch. latifolium (L.) Th. Fries et Lange, 1877, Fl. Dan. 49 (хvii): 7); Скворцов, 1980, в Арктич. фл. СССР, 8: 51; Раст. покр. и раст. ресурсы Пол. Урала, 2006: 117; Мартыненко, Груздев, 2008, Сосуд. раст. респ. Коми: 96.

Обычно по галечниковым берегам рек, на склонах и осыпях. (Ф.С. Леонтьев, 20.08.1936, 23.08.1936, MW).

\section{Hippuridaceae DC.}

60. Hippuris vulgaris L., 1753, Sp. PI. 1: 4; Опред. высш. раст. Коми АCCP, 1962: 253; Мартыненко, 1976, во Фл. северо-вост. Европ. ч. СССР, 3: 220; Ребристая, 1977, Фл. востока Большезем. тундры: 92; Цвелев, 1980, в Арктич. 
фл. СССР, 8: 60; Раст. покр. и раст. ресурсы Пол. Урала, 2006: 118; Мартыненко, Груздев, 2008, Сосуд. раст. респ. Коми: 97.

Берега и мелководья тундровых озер, старицы рек. Обычно.

\section{Apiaceae Lindl. (Umbelliferae Juss.)}

61. Pachypleurum alpinum Ledeb., 1829, Fl. Altaic. 1: 297; Опред. высш. раст. Коми АССР, 1962: 259; Тихомиров, 1977, во Фл. северо-вост. Европ. ч. СССР, 4: 21; Ребристая, 1977, Фл. востока Большезем. тундры: 93; Тихомиров, 1980, в Арктич. фл. СССР, 8: 80; Раст. покр. и раст. ресурсы Пол. Урала, 2006: 119; Мартыненко, Груздев, 2008, Сосуд. раст. респ. Коми: 99.

Разнотравно-моховые и разнотравно-дриадовые тундры, луговины у снежников, разнотравные береговые склоны. Повсеместно. (И.А. Савинов, 19.07.2017, МНА).

62. Angelica decurrens (Ledeb.) B. Fedtsch., 1909, Consp. Fl. Turkestanicae [O.A. Fedchenko \& B.A. Fedchenko] iii. 99; Тихомиров, 1977, во Фл. северо-вост. Европ. ч. СССР, 4: 24; Тихомиров, 1980, в Арктич. фл. СССР, 8: 87; Раст. покр. и раст. ресурсы Пол. Урала, 2006: 118. - Archangelica decurrens Ledeb., 1829, Fl. Altaic. 1: 316-317; Опред. высш. раст. Коми АССР, 1962: 260; Ребристая, 1977, Фл. востока Большезем. тундры: 93; Лащенкова, 1976, во Фл. северо-вост. Европ. ч. СССР, 2: 242; Мартыненко, Груздев, 2008, Сосуд. раст. респ. Коми: 98.

Изредка в приуральской части региона, по кустарниковым зарослям (ивнякам) и увлажненным склонам. (Ф.С. Леонтьев, 08.08.1936, МW).

\section{Pyrolaceae Dumort.}

63. Pyrola grandiflora Rad., 1821, Pyrola \& Chimophila 27-28, pl. 3, f. 2; Опред. высш. раст. Коми АССР, 1962: 263; Кобелева, 1977, во Фл. северо-вост. Европ. ч. СССР, 4: 32; Ребристая, 1977, Фл. востока Большезем. тундры: 93; Раст. покр. и раст. ресурсы Пол. Урала, 2006: 120; Мартыненко, Груздев, 2008, Сосуд. раст. респ. Коми: 100. - P. rotundifolia L., Скворцов, 1980, в Арктич. фл. СССР, 8: 97.

Обычно в разных типах тундр, по склонам. (Ф.С. Леонтьев, 15.08.1936, 01.09.1936, МW).

\section{Ericaceae Juss.}

64. Andromeda polifolia L., 1753, Sp. Pl. 1: 393; Опред. высш. раст. Коми АССР, 1962: 267; Кобелева, 1977, во Фл. северо-вост. Европ. ч. СССР, 4: 40; Ребристая, 1977, Фл. востока Большезем. тундры: 94; Виноградова, Юрцев, 1980, в Арктич. фл. СССР, 8: 133; Раст. покр. и раст. ресурсы Пол. Урала, 2006: 121; Мартыненко, Груздев, 2008, Сосуд. раст. респ. Коми: 101.

В мочажинах на осоковых болотах, изредка.

65. Arctous alpina (L.) Nied., 1889, Bot. Jahrb. Syst. 11(2): 144; Опред. высш. раст. Коми АССР, 1962: 268; Кобелева, 1977, во Фл. северо-вост. Европ. ч. СССР, 4: 42; Ребристая, 1977, Фл. востока Большезем. тундры: 95; Виноградова, Юрцев, 1980, в Арктич. фл. СССР, 8: 139; Раст. покр. и раст. ресурсы Пол. Урала, 2006: 121; Мартыненко, Груздев, 2008, Сосуд. раст. респ. Коми: 101.

В сухих пятнистых кустарничковых и ерниковых, кустарничково-моховых тундрах. (Ф.С. Леонтьев, 19.08.1936, $\mathrm{MW})$.

66. Harrimanella hypnoides (L.) Coville, 1901, Proc. Wash. Acad. Sci., 3(21): 575; Опред. высш. раст. Коми ACCР, 1962 : 267; Кобелева, 1977, во Фл. северо-вост. Европ. ч. СССР, 4: 39; Ребристая, 1977, Фл. востока Большезем. тундры: 94; Юрцев, 1980, в Арктич. фл. СССР, 8: 132; Раст. покр. и раст. ресурсы Пол. Урала, 2006: 121; Мартыненко, Груздев, 2008, Сосуд. раст. респ. Коми: 102.

Изредка на каменистых склонах, в моховых тундрах.

67. Ledum decumbens (Aiton) Lodd. ex Steud., 1840, Nomencl. Bot. (ed. 2) 2: 20; Опред. высш. раст. Коми АССР, 1962: 266; Кобелева, 1977, во Фл. северо-вост. Европ. ч. СССР, 4: 38; Ребристая, 1977, Фл. востока Большезем. тундры: 94; Раст. покр. и раст. ресурсы Пол. Урала, 2006: 122; Мартыненко, Груздев, 2008, Сосуд. раст. респ. Коми: 102. - L. palustre subsp. decumbens (Aiton) Hult., Виноградова, Юрцев, 1980, в Арктич. фл. СССР, 8: 110.

Обычно по сухим пятнистым кустарничковым тундрам.

68. Vaccinium vitis-idaea L., 1753, Sp. PI. 1: 351; Опред. высш. раст. Коми АССР, 1962: 268; Кобелева, 1977, во Фл. северо-вост. Европ. ч. СССР, 4: 44; Ребристая, 1977, Фл. востока Большезем. тундры: 95; Виноградова, Юрцев, 1980, в Арктич. фл. СССР, 8: 152; Раст. покр. и раст. ресурсы Пол. Урала, 2006: 123; Мартыненко, Груздев, 2008, Сосуд. раст. респ. Коми: 103. 
Встречается часто в тундровых сообществах, особенно в пятнистых кустарничковых и ерниковых тундрах. Представлен северной расой - subsp. minus (Lodd.) Hult.

69. V. uliginosum L., 1753, Sp. PI. 1: 350; Опред. высш. раст. Коми АССР, 1962: 269; Кобелева, 1977, во Фл. северовост. Европ. 4. СССР, 4: 43; Ребристая, 1977, Фл. востока Большезем. тундры: 95; Виноградова, Юрцев, 1980, в Арктич. фл. СССР, 8: 146; Раст. покр. и раст. ресурсы Пол. Урала, 2006: 123; Мартыненко, Груздев, 2008, Сосуд. раст. респ. Коми: 102.

В разных типах тундр (ерниковые, ивняковые, сухие кустарничковые), обычно. Представлен северной расой subsp. microphyllum Lange.

\section{Primulaceae Vent.}

70. Androsace lehmanniana Spreng., 1817, Isis (Oken) 1: 1289, pl. 9; Раст. покр. и раст. ресурсы Пол. Урала, 2006: 123; Мартыненко, Груздев, 2008, Сосуд. раст. респ. Коми: 103. - A. bungeana Schischk. et Bobr., 1952, FI. URSS 18: 231 232, pl. 13, f. 1; Опред. высш. раст. Коми АССР, 1962: 270; Лащенкова, 1977, во Фл. северо-вост. Европ. 4. СССР, 4: 51; Ребристая, 1977, Фл. востока Большезем. тундры: 95. - A. chamaejasme Wulfen in Jacq., Коробков, 1980, в Арктич. фл. CCCP, 8: 180.

Сухие дриадовые тундры, расщелины скал, песчано-галечниковые отмели. Беломраморный каньон, на склонах. (И.А. Савинов, 21.07.2017, МНА). Рис. 4, 3.

\section{Polemoniaceae Juss.}

71. Polemonium acutiflorum Willd. ex Roem. et Schult., 1819, Syst. Veg. (ed. 15 bis) 4: 792; Опред. высш. раст. Коми АССР, 1962: 276; Толмачев, 1977, во Фл. северо-вост. Европ. ч. СССР, 4: 68; Ребристая, 1977, Фл. востока Большезем. тундры: 96; Цвелев, 1980, в Арктич. фл. СССР, 8: 218; Раст. покр. и раст. ресурсы Пол. Урала, 2006: 125; Мартыненко, Груздев, 2008, Сосуд. раст. респ. Коми: 108.

Повсеместно в сырых местообитаниях (заболоченные тундры, ивняки, разнотравные луга).

72. P. boreale Adams, 1817, Mém. Soc. Imp. Naturalistes Moscou 5: 92-94; Опред. высш. раст. Коми АССР, 1962: 276 (as var. nudipedum Klok.); Толмачев, 1977, во Фл. северо-вост. Европ. ч. СССР, 4: 68; Ребристая, 1977, Фл. востока Большезем. тундры: 97; Цвелев, 1980, в Арктич. фл. СССР, 8: 220; Раст. покр. и раст. ресурсы Пол. Урала, 2006: 126; Мартыненко, Груздев, 2008, Сосуд. раст. респ. Коми: 108.

Песчаные береговые склоны, галечники, осыпи. Редко. В Красной книге ЯНАО, статус 3 (2010)!

\section{Boraginaceae Juss.}

73. Eritrichium nanum subsp. villosum (Ledeb.) Brand, 1931, Das Pflanzenreich 97[IV,252]: 189-190. - Eritrichium villosum (Ledeb.) Bunge, 1836, Verz. Altai Pfl. 14; Опред. высш. раст. Коми АCCP, 1962: 281; Мартыненко, 1977, во Фл. северо-вост. Европ. ч. СССР, 4: 79; Ребристая, 1977, Фл. востока Большезем. тундры: 97; Петровский, 1980, в Арктич. фл. СССР, 8: 240; Раст. покр. и раст. ресурсы Пол. Урала, 2006: 126; Мартыненко, Груздев, 2008, Сосуд. раст. респ. Коми: 109.

Разнотравные береговые склоны, луговины, около снежников, иногда в тундре. Встречен близ водопада в нижнем течении р. Хальмерью. На моховине среди камней.

\section{Lamiaceae Lindl. (Labiatae Juss.)}

*74. Thymus reverdattoanus Serg. aggr., 1936, Animadvers. Syst. Herb. Univ. Tomsk. Nos. I-2, p. 5; Меницкий, Юрцев, 1980, в Арктич. фл. СССР, 8: 257; Раст. покр. и раст. ресурсы Пол. Урала, 2006: 128.

Следуя морфологическим признакам и данным географии («Арктическая флора СССР», т. 8, 1980), именно так определяются образцы, собранные автором в приполярной части долины р. Кары. На Полярном Урале указывается вид T. paucifolius Klok., восточнее, в арктических районах Сибири, распространен T. extremus Klok. Наши экземпляры имеют черепитчато налегающие скученные листья, больше соответствующие расе T. extremus Klok. Склоны, береговые обнажения, редко. (И.А. Савинов, 21.07.2017, МНА). Типовая раса агрегата и T. paucifolius Klok. в Красной книге ЯНАО, статус 3 (2010)! В сводке О.В. Ребристой (1977) указан только один вид - T. subarcticus Klok. et Schost., распространенный южнее (рр. Воркута, Уса).

\section{Orobanchaceae Vent.}

75. Bartsia alpina L., nom. cons., 1753, Sp. PI. 2: 602; Опред. высш. раст. Коми ACCP, 1962: 297; Иванина, 1977, во Фл. северо-вост. Европ. ч. СССР, 4: 122; Ребристая, 1977, Фл. востока Большезем. тундры: 98; Ребристая, 1980, в 
Savinov, I. A. New materials for flora of Kara river.... Acta Biologica Sibirica, 2018, 4(1), 52-72

Арктич. фл. СССР, 8: 292; Раст. покр. и раст. ресурсы Пол. Урала, 2006: 129; Мартыненко, Груздев, 2008, Сосуд. раст. респ. Коми: 113.

Разнотравные береговые склоны в долинах рек. В массе по склонам дриадовой тундры у водопада Буредан. (И.А. Савинов, 25.07.2017, МНА). В Красной книге ЯНАО, статус 3 (2010)!

76. Castilleja lapponica Gand. ex Rebrist., 1964, Novosti Sist. Vyssh. Rast., 1 (Leningrad): 293; Иванина, 1977, во Фл. северо-вост. Европ. ч. СССР, 4: 114; Ребристая, 1977, Фл. востока Большезем. тундры: 98; Ребристая, 1980, в Арктич. фл. СССР, 8: 284; Раст. покр. и раст. ресурсы Пол. Урала, 2006: 129; Мартыненко, Груздев, 2008, Сосуд. раст. респ. Коми: 113.

На разнотравных склонах и осыпях, скалистых обнажениях. Встречен только в районе устья р. Брусьяхи. (Ф.С. Леонтьев, 04.08.1936, 07.08.1936, 10.08.1936, MW). Редко, нуждается в охране! Красная книга НАО, статус 3 (2006)! Рис. 4, п.

77. Pedicularis labradorica Wirsing, 1778, Eclog. Bot. [2], pl. 10; Опред. высш. раст. Коми АССР, 1962: 298; Иванина, 1977, во Фл. северо-вост. Европ. ч. СССР, 4: 129; Ребристая, 1977, Фл. востока Большезем. тундры: 98; Иванина, 1980, в Арктич. фл. СССР, 8: 309; Раст. покр. и раст. ресурсы Пол. Урала, 2006: 131; Мартыненко, Груздев, 2008, Сосуд. раст. респ. Коми: 115.

Разные типы кустарниковых тундр. Ерниковая лишайниково-моховая тундра на подходе к хребту Оченырд, на пупыре (Приуральская часть территории). (Ф.С. Леонтьев, 01.10.1936, МW). Рис. 4, А.

78. P. oederi Vahl ex Hornem., 1806, Fors. Oecon. Plantel. (ed. 2) 580-581; Опред. высш. раст. Коми АССР, 1962: 300; Иванина, 1977, во Фл. северо-вост. Европ. ч. СССР, 4: 131; Ребристая, 1977, Фл. востока Большезем. тундры: 99; Иванина, 1980, в Арктич. фл. СССР, 8: 297; Раст. покр. и раст. ресурсы Пол. Урала, 2006: 131; Мартыненко, Груздев, 2008, Сосуд. раст. респ. Коми: 115.

Снежники, кустарниковые тундры. Правый берег р. Кары, близ устья р. Нерусавэйяхи, «малый каньон», в тундре. (И.А. Савинов, 24.07.2017, МНА). (Ф.С. Леонтьев, 16.08.1936, МW). Рис. 4, А.

79. P. sudetica Willd., 1800, Sp. PI. 3(1): 209; Опред. высш. раст. Коми АССР, 1962: 299; Иванина, 1977, во Фл. северо-вост. Европ. ч. СССР, 4: 129; Ребристая, 1977, Фл. востока Большезем. тундры: 99; Иванина, 1980, в Арктич. фл. СССР, 8: 311; Раст. покр. и раст. ресурсы Пол. Урала, 2006: 131; Мартыненко, Груздев, 2008, Сосуд. раст. респ. Коми: 116.

Сырые тундры и болота, увлажненные луга. Правый берег р. Кары у устья р. Лядхэйяхи, в тундре. (И.А. Савинов, 19.07.2017, МНА). Рис. 4, и.

\section{Plantaginaceae Juss.}

80. Veronica longifolia L., 1753, Sp. PI. 1: 10; Опред. высш. раст. Коми АССР, 1962: 294; Иванина, 1977 , во Фл. северо-вост. Европ. ч. СССР, 4: 109; Ребристая, 1977, Фл. востока Большезем. тундры: 97; Коробков, 1980, в Арктич. фл. СССР, 8: 270; Раст. покр. и раст. ресурсы Пол. Урала, 2006: 132; Мартыненко, Груздев, 2008, Сосуд. раст. респ. Коми: 117.

Приречные заросли ив, разнотравные береговые склоны. Часто. (Ф.С. Леонтьев, 1936 г., МW).

\section{Lentibulariaceae Rich.}

81. Pinguicula alpina L., 1753, Sp. PI. 1: 17; Опред. высш. раст. Коми АССР, 1962: 301; Мартыненко, 1977 , во Фл. северо-вост. Европ. ч. СССР, 4: 134; Ребристая, 1977, Фл. востока Большезем. тундры: 99; Цвелев, 1983, в Арктич. фл. СССР, 8(2): 8; Раст. покр. и раст. ресурсы Пол. Урала, 2006: 132; Мартыненко, Груздев, 2008, Сосуд. раст. респ. Коми: 118.

Моховые ивняки, береговые откосы, слабо задернованные участки. На мшистых куртинках по склонам Беломраморного каньона на р. Кара. (И.А. Савинов, 21.07.2017, МНА). В Красной книге яНАО, статус 3 (2010), Красной книге НАО, статус 3 (2006)! Рис. 4, ж.

\section{Rubiaceae Juss.}

82. Galium boreale L., 1753, Sp. PI. 1: 108; Опред. высш. раст. Коми АССР, 1962: 303; Мартыненко, 1977, во Фл. северо-вост. Европ. ч. СССР, 4: 143; Ребристая, 1977, Фл. востока Большезем. тундры: 99; Цвелев, 1987, в Арктич. фл. СССР, 10: 12; Раст. покр. и раст. ресурсы Пол. Урала, 2006: 133; Мартыненко, Груздев, 2008, Сосуд. раст. респ. Коми: 105. - G. septentrionale sensu Pobed. (auct. non Roem. et Schult.)

Разнотравные береговые склоны, ивняки, часто. Наши растения отличаются от типичного G. boreale более широкими листьями и широко раскидистыми соцветиями, что соответствует другому таксону - G. septentrionale. Это также отмечает в своей сводке О.В. Ребристая (1977). Такая же ситуация наблюдается и на Южном Ямале 
(Савинов, 2014). По данным А.M. Elkordy, I.A. Schanzer (2015), эти виды также отличаются характером опушения поверхности мерикарпиев (у G. septentrionale - редкие, цепляющиеся трихомы; у G. boreale - густые, плотно расположенные, крючковатые трихомы). (И.А. Савинов, 29.07.2017, МНА). Рис. 4, С.

83. G. uliginosum L., 1753, Sp. PI. 1: 106; Опред. высш. раст. Коми АССР, 1962: 304; Мартыненко, 1977, во Фл. северо-вост. Европ. ч. СССР, 4: 142; Ребристая, 1977, Фл. востока Большезем. тундры: 99; Цвелев, 1987, в Арктич. фл. СССР, 10: 21; Раст. покр. и раст. ресурсы Пол. Урала, 2006: 134; Мартыненко, Груздев, 2008, Сосуд. раст. респ. Коми: 106. $\mathrm{MHA})$.

Сырые ивняки, луговины, окраины осоковых болот. Собран у устья р. Брусьяхи. (И.А. Савинов, 27.07.2017,

84. G. densiflorum Ledeb., 1829, Fl. Altaic. [Ledebour]. 1: 137; Мартыненко, 1977, во Фл. северо-вост. Европ. ч. СССР, 4: 144; Цвелев, 1987, в Арктич. фл. СССР, 10: 17; Раст. покр. и раст. ресурсы Пол. Урала, 2006: 133; Мартыненко, Груздев, 2008, Сосуд. раст. респ. Коми: 105.

Разнотравное луговое сообщество в долине р. Кары, левый берег, около 7 км ниже водопада Буредан. (И.А. Савинов, 26.07.2017, МНА). Вид не отмечен в сводке О.В. Ребристой (1977). Красная книга НАО, статус 1 (2006)! Рис. 4, H.

\section{Valerianaceae Batsch.}

85. Valeriana capitata Pall. ex Link, 1820, Jahrb. Gewächsk. 1(3): 66; Опред. высш. раст. Коми АССР, 1962: 306; Миняев, 1977, во Фл. северо-вост. Европ. ч. СССР, 4: 153; Ребристая, 1977, Фл. востока Большезем. тундры: 100; Соколова, 1987, в Арктич. фл. СССР, 10: 35; Раст. покр. и раст. ресурсы Пол. Урала, 2006: 135; Мартыненко, Груздев, 2008, Сосуд. раст. респ. Коми: 107.

Ивняковые и ерниковые тундры, заросли ивняков. Часто. (И.А. Савинов, 19.07.2017, МНА).

\section{Campanulaceae Juss.}

86. Campanula rotundifolia L., 1753, Sp. PI. 1: 163; Опред. высш. раст. Коми АCСР, 1962: 308; Кобелева, 1977, во Фл. северо-вост. Европ. ч. СССР, 4: 158; Ребристая, 1977, Фл. востока Большезем. тундры: 100; Юрцев, 1987, в Арктич. фл. СССР, 10: 42; Раст. покр. и раст. ресурсы Пол. Урала, 2006: 135; Мартыненко, Груздев, 2008, Сосуд. раст. респ. Коми: 119. - C. langsdorffiana (A. DC.) Fisch. ex Trautv. \& C.A. Mey, 1856, Reise Sibir., 1(2, Lfg. 3): 60; Ребристая, 1977, Фл. востока Большезем. тундры: 100.

Песчаные бугры, сухие береговые склоны. В долине р. Кары, по галечникам и песчаным косам. Нередко. (Ф.С. Леонтьев, 1936 г., МW).

\section{Asteraceae Bercht. \& J. Presl (Compositae Giseke)}

87. Eurybia sibirica (L.) G.L. Nesom, 1994[1995], Phytologia 77(3): 261. - Aster sibiricus L., 1753, Sp. PI. 2: 872; Опред. высш. раст. Коми АССР, 1962: 315; Петровский, 1987, в Арктич. фл. СССР, 10: 67; Раст. покр. и раст. ресурсы Пол. Урала, 2006: 136; Мартыненко, Груздев, 2008, Сосуд. раст. респ. Коми: 121. - Aster subintegerrimus (Trautv.) Ostenf. et Resvoll, Nyt Mag. Naturvidensk. liv. 1916: 163; Токаревских, 1977, во Фл. северо-вост. Европ. ч. СССР, 4: 165; Ребристая, 1977, Фл. востока Большезем. тундры: 101. - Aster subintegerrimus Trautv., 1847, Reise Eur. As. Afr. 1: 161.

Песчаные и галечниковые берега рек. В массе по галечникам и склонам к реке, устье р. Силовояхи. (Ф.С. Леонтьев, 12.08.1936, MW).

88. Tripleurospermum hookeri Sch. Bip., 1853, Bonplandia (Hannover) 1: 151; Цвелев, 1987, в Арктич. фл. СССР, 10: 127; Мартыненко, Груздев, 2008, Сосуд. раст. респ. Коми: 127. - T. phaeocephalum (Rupr.) Pobed., 1961, Bot. Mater. Gerb. Bot. Inst. Komarova Akad. Nauk SSSR 21: 347; Токаревских, 1977, во Фл. северо-вост. Европ. ч. СССР, 4: 180; Ребристая, 1977, Фл. востока Большезем. тундры: 102; Раст. покр. и раст. ресурсы Пол. Урала, $2006: 144$.

Береговые склоны, песчаные обрывы, в расщелинах камней. Нередко. Правый берег р. Кары, ниже устья р. Брусьяхи. Также на р. Хальмерью. (И.А. Савинов, 28.07.2017, МНА).

89. Tanacetum bipinnatum (L.) Sch. Bip., 1844, Ueber Tanaceteen 48; Токаревских, 1977, во Фл. северо-вост. Европ. ч. СССР, 4: 181; Ребристая, 1977, Фл. востока Большезем. тундры: 102; Цвелев, 1987, в Арктич. фл. СССР, 10: 122; Раст. покр. и раст. ресурсы Пол. Урала, 2006: 142; Мартыненко, Груздев, 2008, Сосуд. раст. респ. Коми: 130.

Песчаные разнотравные склоны, ивняки, галечники у реки. Повсеместно, в массе. Собран на правом берегу р. Кара близ устья р. Нерусавэйяха, «малый каньон», на склонах (И.А. Савинов, 24.07.2017, МНА). (Ф.С. Леонтьев, 03.08.1936, б/даты, МW). 
90. Artemisia norvegica Fries, 1817, Novit. Fl. Suec. 56; Опред. высш. раст. Коми ACCP, 1962: 322; Токаревских, 1977, во Фл. северо-вост. Европ. ч. СССР, 4: 186; Коробков, 1987, в Арктич. фл. СССР, 10: 151; Раст. покр. и раст. ресурсы Пол. Урала, 2006: 137; Мартыненко, Груздев, 2008, Сосуд. раст. респ. Коми: 121.

Слабо задернованные песчаные склоны, речные террасы. Вид не указан в сводке О.В. Ребристой (1977). Красная книга НАО, статус 1 (2006), Красная книга ЯНАО, статус 2 (2010)! Pис. 4, М.

91. Senecio integrifolius (L.) Clairv., 1811, Man. Herbor. Suisse 241; Опред. высш. раст. Коми ACCP, 1962: 326; Токаревских, 1977, во Фл. северо-вост. Европ. Ч. СCCP, 4: 194 (as S. campester (Reiz.) DC); Ребристая, 1977, Фл. востока Большезем. тундры: 103; Коробков, Юрцев, 1987, в Арктич. фл. СССР, 10: 218; Раст. покр. и раст. ресурсы Пол. Урала, 2006: 142. - Tephroseris integrifolia (L.) Holub, Мартыненко, Груздев, 2008, Сосуд. раст. респ. Коми: 131.

Ерниковые и ивняковые тундры, кустарники, разнотравные береговые склоны. Разнотравный западный склон вдоль ручья у подножья хребта Оченырд (высота около 350 м н.у.м.). Рис. 4, Б.

92. Tephroseris palustris (L.) Rchb., 1842, Flora Saxon. 146; Мартыненко, Груздев, 2008, Сосуд. раст. респ. Коми: 131. - Senecio arcticus Rupr., 1845, Beitr. Pflanzenk. Russ. Reiches 44; Ребристая, 1977, Фл. востока Большезем. тундры: 103. - S. congestus (R.Br.) DC, 1837[1838], Prodr. 6: 363; Опред. высш. раст. Коми АССР, 1962: 326; Токаревских, 1977, во Фл. северо-вост. Европ. Ч. СССР, 4: 194; Коробков, Юрцев, 1987, в Арктич. фл. СССР, 207: 12; Раст. покр. и раст. ресурсы Пол. Урала, 2006: 143.

Берег озера близ устья р. Лядхэйяхи, в массе. Аспектирует.

93. Achillea millefolium L., 1753, Sp. PI. 2: 899; Опред. высш. раст. Коми АCСР, 1962: 319; Токаревских, 1977, во Фл. северо-вост. Европ. Ч. СССР, 4: 177; Ребристая, 1977, Фл. востока Большезем. тундры: 102; Цвелев, 1987, в Арктич. фл. СССР, 10: 109; Раст. покр. и раст. ресурсы Пол. Урала, 2006: 136; Мартыненко, Груздев, 2008, Сосуд. раст. респ. Коми: 120.

Крутые склоны, разнотравные луговины. Повсеместно.

94. Solidago virgaurea L., 1753, Sp. PI. 2: 880; Опред. высш. раст. Коми АCCP, 1962: 314; Токаревских, 1977, во Фл. северо-вост. Европ. ч. СССР, 4: 164; Ребристая, 1977, Фл. востока Большезем. тундры: 101; Ребристая, 1987, в Арктич. фл. СССР, 10: 65; Раст. покр. и раст. ресурсы Пол. Урала, 2006: 142; Мартыненко, Груздев, 2008, Сосуд. раст. респ. Коми: 130.

Ерниковые и ивняковые тундры, разнотравные луговые склоны. Луговой разнотравный склон у устья $\mathrm{p}$. Силовояхи. (Ф.С. Леонтьев, 24.08.1936, МW). Рис. 4, С.

95. Saussurea alpina (L.) DC, 1810, Ann. Mus. Natl. Hist. Nat. 16: 198; Опред. высш. раст. Коми ACCP, 1962: 331; Токаревских, 1977, во Фл. северо-вост. Европ. ч. СССР, 4: 199; Ребристая, 1977, Фл. востока Большезем. тундры: 104; Коробков, Юрцев, 1987, в Арктич. фл. СССР, 10: 243; Раст. покр. и раст. ресурсы Пол. Урала, 2006: 141; Мартыненко, Груздев, 2008, Сосуд. раст. респ. Коми: 128.

Изредка в разных типах тундры, разнотравных береговых склонах.

96. Taraxacum lapponicum Kihlm. ex Hand. - Mazz., 1907, Monogr. Gatt. Taraxacum: 73; Орлова, 1977, во Фл. северо-вост. Европ. ч. СССР, 4: 215; Ребристая, 1977, Фл. востока Большезем. тундры: 104. - T. croceum Dahlst., Цвелев, 1987, в Арктич. фл. СССР, 10: 275; Раст. покр. и раст. ресурсы Пол. Урала, 2006: 143; Мартыненко, Груздев, 2008, Сосуд. раст. респ. Коми: 129.

Галечные отмели близ устья р. Силовояхи, изредка. (Д. Плохотнюк, опр. И.А. Савинов, 29.07.2017, МНА).

97. Petasites radiatus (J.F. Gmel.) Toman, 1972, Folia Geobot. Phytotax. 7(4): 388; Мартыненко, Груздев, 2008, Сосуд. раст. респ. Коми: 127 (as P. radiatus (J.F. Gmel.) Holub); Коробков, Юрцев, 1987, в Арктич. фл. СССР, 10: 180. Nardosmia laevigata DC, 1836, Prodr. [A. P. de Candolle] 5: 205; Опред. высш. раст. Коми АССР, 1962: 324; Токаревских, 1977, во Фл. северо-вост. Европ. ч. СССР, 4: 189; Ребристая, 1977, Фл. востока Большезем. тундры: 103; Раст. покр. и раст. ресурсы Пол. Урала, 2006: 141.

Обычно по галечниковым и песчаным отмелям рек.

\section{Заключение}

Таким образом, в ходе двухнедельной поездки в районе исследований было выявлено 97 видов сосудистых растений, относимых к 74 родам из 34 семейств, что составляет примерно $20 \%$ всего видового разнообразия флоры региона - 475 видов (Ребристая, 1977). Таксономическая структура местной флоры вполне соответствует статистическим показателям, свойственным тундровым районам России, с явным преобладанием представителей семейств злаковых, осоковых, гвоздичных, лютиковых и сложноцветных. Отличительной особенностью местной флоры можно считать ее смешанный (экотонный) характер, поскольку здесь проходят границы ареалов многих европейских и сибирских видов. Были выявлены сибирские виды (часть из них - азиатско-западноамериканские), 
проникающие на европейский Север (Rhodiola quadrifida, Minuartia macrocarpa, Caltha arctica), а также факт совместной встречаемости в изученном районе европейских и сибирских таксонов растений из одного рода (виды родов Trollius, Thymus). Выявлены новые местонахождения для ряда видов (Caltha arctica R.Br., Ranunculus pedatifidus var. affinis (R. Br.) L.D. Benson, R. reptans L.); некоторые виды ранее не были указаны во флоре региона (Viola epipsiloides Löve et D. Löve, Galium densiflorum Ledeb., Artemisia norvegica Fries). Отмечены более богатые по видовому разнообразию сообщества (разнотравно-дриадовая тундра, скальные стенки в каньонах рек) и менее богатые (осоково-сфагновая заболоченная тундра). Обращает на себя внимание факт полного отсутствия на маршруте адвентивной (чужеродной) фракции флоры (хотя отдельные виды, например, Chamaenerion angustifolium (L.) Scop., в условиях некоторых биотопов могут приобретать признаки «адвентивности»), представленной заносными видами, поскольку исследованная территория отличается слабой степенью антропогенной нагрузки, включающей, главным образом, вездеходные дороги вдоль долин рек, а также обозы и временные стоянки оленеводов-кочевников (здесь исключены, разумеется, ближайшие окрестности г. Воркуты и заброшенный пос. Хальмерь-Ю, а также дорога ПАО «Газпром» по эксплуатации объектов в рамках мегапроекта «ямал»).

В ходе проведенного исследования было выявлено 16 видов (таблица 2), включенных в региональные Красные книги (НАО, ЯНАО и Коми), для которых установлены новые местонахождения. В связи с этим важны мероприятия по охране природных популяций растений и их местообитаний. Среди них 11 видов включены в Красную книгу НАО, 6 видов - в Красную книгу ЯНАО и 8 видов - в Красную книгу республики Коми. В региональные списки охраняемых видов есть все основания включить еще два вида, Ranunculus pedatifidus var. affinis (R. Br.) L.D. Benson и Caltha arctica R.Br., поскольку частоту их встречаемости можно охарактеризовать как «редко» (встречены на маршруте всего 1-3 раза). Ранее они не были включены в подобные региональные сводки. Изученный регион представляется исключительно интересным, поскольку он расположен на границе между сибирской и европейской арктическими и субарктическими флорами и в Карской тундре встречаются многие виды из обоих секторов Арктики.

Таблица 2. Редкие и исчезающие виды сосудистых растений, включенные в региональные Красные книги (указаны категории видов)

\begin{tabular}{|c|c|c|c|c|}
\hline Перечень видов & $\begin{array}{l}\text { Шкала встречаемости } \\
\text { видов (редко - вид на } \\
\text { маршруте встречен 1-3 } \\
\text { раза, изредка - 4-10 раз, } \\
\text { нередко - более } 10 \text { раз, } \\
\text { часто - регулярно на } \\
\text { протяжении всего } \\
\text { маршрута) }\end{array}$ & $\begin{array}{l}\text { Красная книга } \\
\text { НАО (2006) }\end{array}$ & $\begin{array}{l}\text { Красная книга } \\
\text { республики } \\
\text { Коми (2009) }\end{array}$ & $\begin{array}{l}\text { Красная } \\
\text { книга } \\
\text { янАО } \\
(2010)\end{array}$ \\
\hline Tofieldia coccinea Rich. & изредка & $+(3)$ & $+(3)$ & \\
\hline Minuartia macrocarpa (Pursh) Ostenf. & изредка & $+(3)$ & & \\
\hline Silene paucifolia Ledeb. & изредка & $+(3)$ & $+(3)$ & \\
\hline Dianthus repens Willd. & редко & & $+(3)$ & \\
\hline Trollius apertus Perf. ex Igoschina & часто & $+(3)$ & $+(4)$ & \\
\hline Delphinium middendorfii Trautv. & редко & $+(3)$ & $+(4)$ & \\
\hline $\begin{array}{l}\text { Papaver lapponicum (Tolm.) Nordh. } \\
\text { subsp. jugoricum Tolm. }\end{array}$ & изредка & & $+(2)$ & \\
\hline Draba glacialis Adams. & редко & $+(3)$ & $+(4)$ & \\
\hline Rhodiola quadrifida (Pall.) Fisch. et Mey. & редко & $+(3)$ & $+(2)$ & $+(3)$ \\
\hline Polemonium boreale Adams. & редко & & & $+(3)$ \\
\hline Thymus reverdattoanus Serg. aggr. & изредка & & & $+(3)$ \\
\hline Bartsia alpina $\mathrm{L}$. & редко & & & $+(3)$ \\
\hline Castilleja lapponica Gand. & редко & $+(3)$ & & \\
\hline Pinguicula alpina $\mathrm{L}$. & редко & $+(3)$ & & $+(3)$ \\
\hline Galium densiflorum Ledeb. & редко & $+(1)$ & & \\
\hline Artemisia norvegica Fries & редко & $+(1)$ & & $+(2)$ \\
\hline
\end{tabular}

\section{Благодарности}

Автор благодарит организаторов и руководителей учебной экспедиции Центра «На Донской» ГБПОУ «Воробьевы горы» С.В. Рупасова и Е.В. Комарову, их помощников - Н.Н. Парамонычева, С. Александрова, А. Александрову, Д. Куваева, наших школьников, проходивших учебную практику, а также к.б.н., к.филос.н. Д.В. Моргуна (МДЮЦ ЭКТ, г. Москва) за содействие в финансировании данной экспедиции. Благодаря любезности 
Savinov, I. A. New materials for flora of Kara river.... Acta Biologica Sibirica, 2018, 4(1), 52-72

д.б.н. А.В. Щербакова (МГУ) автор имел возможность познакомиться со сборами с Полярного Урала, хранящимися в MW (в частности, Карской экспедиции 1936 года).

\section{References}

Arkticheskaja flora SSSR. (1960-1987). A.I. Tolmachev, B.A. Yurtzev (eds.). Iss. I-X. Moscow \& Leningrad: Nauka. (in Russian)

Cherepanov S.K. (1995). Sosudistye rastenija Rossii i sopredel'nyh gosudarstv (v predelah byvshego SSSR). SPb.: Mir i sem'ja-95, 990. (in Russian)

Elkordy A.M., Schanzer I.A. (2015). Fruit morphology in Galium section Platygalium (Rubiaceae) and its potential taxonomic significance. Turczaninowia, 18, 1, 82-89.

Flora Severo-Vostoka Evropejskoj chasti SSSR. (1974-1977). A.I. Tolmachev (ed.). Vol. 1-4. L.: Nauka. (in Russian)

Frizen N.V. (1993). Trollius. Flora Sibiri. Vol. 6. Portulacaceae - Ranunculaceae, Novosibirsk: VO Nauka, Sibirskaja izdatel'skaja firma, 103-108. (in Russian)

Krasnaja kniga Neneckogo avtonomnogo okruga. (2006). N.V. Matveeva (ed.). Naryan-Mar: Nenetsky Informaticanalytical Center, 435. (in Russian)

Krasnaja kniga Respubliki Komi (redkie i nahodjashhiesja pod ugrozoj ischeznovenija vidy rastenij i zhivotnyh). (2009).

A.I. Taskaev (ed.). Syktyvkar: Biological Inst. Komi NC UB RAS, 791. (in Russian)

Krasnaja kniga Jamalo-Neneckogo avtonomnogo okruga: zhivotnye, rastenija, griby. (2010). S. N. Ektova, D.O. Zamjatin (eds.). Ekaterinburg: Publ. House Basko, 308. (in Russian)

Kuliyev A.N., Morozov V.V. (1988). Floristic findings in the East Bolshezemelskaya tundra and in the Polar Urals. Botanicheskij zhurnal, 73, 3, 443-447. (in Russian)

Kuliyev A.N., Morozov V.V. (1991). New data on distribution of vascular plants in the Pay-Hoy and Polar Ural. Botanicheskij zhurnal, 76, 9, 1323-1330. (in Russian)

Martynenko V.A., Gruzdev B.I. (2008). Sosudistye rastenija Respubliki Komi. Syktyvkar: Institut biologii Komi NC UrO RAN, 136. (in Russian)

Opredelitel' vysshih rastenij Komi ASSR. (1962). A.I. Tolmachev (ed.), authors: Bolotova V.M., Dedov A.A., Lashhenkova A.N., Tolmachev A.I., Sholeninova T.P. M.-L.: AN USSR, 359. (in Russian)

Rastitel'nyj pokrov i rastitel'nye resursy Poljarnogo Urala. (2006). P.L. Gorchakovskij (ed.). Ekaterinburg: Publ. House Ural Univ., 796. (in Russian)

Rebristaja O.V. (1977). Flora vostoka Bol'shezemel'skoj tundry. L.: Nauka, 334. (in Russian)

Rupreht F.I. (1856). Flora Severnogo Urala. O rasprostranenii rastenij na Severnom Urale (Po rezul'tatam Geograficheskoj jekspedicii 1847 i 1848 godov). In: Gofman Je.K. Severnyj Ural i beregovoj hrebet Paj-Hoj, t. 2 (Pribavlenie). St.-Petersburg, 51. (in Russian)

Savinov I.A. (2014). Flora of vascular plants materials of the middle stream of Shhuch'ja river (Southern Yamal). Phytodiversity of Eastern Europe, 8, 3, 81-86. (in Russian)

Savinov I.A. (2016). Additions and corrections to the flora of vascular plants of the Southern Yamal (valley of the Shhuch'ja river). Samarskaja Luka: problemy regional'noj i global'noj jekologii, 25, 2, 207-210. (in Russian)

Shrenk A.I. (2009). Puteshestvie k severo-vostoku Evropejskoj Rossii cherez tundry samoedov k severnym Ural'skim goram. M.: OGl, 496. (in Russian)

Skvortsov V.Je. (2000). .Atlas-opredelitel' sosudistyh rastenij taezhnoj zony Evropejskoj Rossii. M.: Grinpis Rossii, 587. (in Russian)

\section{Citation:}

Savinov, I. A. (2018). New materials for flora of vascular plants of the middle stream of Kara river (north-east of the Bolshezemelskaya tundra). Acta Biologica Sibirica, 4 (1), 52-72.

Submitted: 08.12.2017. Accepted: 05.02.2018

crossref http://dx.doi.org/10.14258/abs.v4i1.3917

(C) 2018 by the authors. Submitted for possible open access publication under the terms and conditions of the Creative Commons Attribution (CC BY) license (http://creativecommons.org/licenses/by/4.0/). 